\title{
La ejecución de las sentencias urbanísticas con especial referencia a la imposibilidad legal y material.
}

\author{
Venancio Gutiérrez Colomina \\ Secretario General del Ayuntamiento de Málaga \\ Profesor Asociado de Derecho Administrativo \\ (Profesor Titular Acreditado por la ANECA) \\ Universidad de Málaga
}

SUMARIO. I. EL ESTADO DE LA GUESTIÓN EN LA EJEGUCIÓN DE LAS SENTENGIAS URBANÍSTICAS. 1. Factores y causas que originan la especial dificultad de ejecutar las Sentencias Urbanísticas. 2. Mecanismos preventivos y represivos autonómicos y municipales, ante la construcción ilegal. A. Ideas Generales. B. Legislación autonómica de incidencia en las demoliciones de edificaciones ilegales. C. Reposición exprés de la realidad física alterada por obras manifiestamente incompatibles con la ordenación urbanística. D. Las parcelaciones ilegales en el SNU. 3. La nulidad de los planes urbanísticos y los efectos perversos de la impugnación indirecta y de la acción pública. A. Punto de partida: Naturaleza jurídica de Disposición General. B. La impugnación indirecta del Planeamiento. C. La acción pública. D. La distinción entre los actos de tramitación del Plan y el Plan en sí. E. Efectos de la nulidad del Planeamiento. a). Efectos Generales. b). En el Planeamiento de Desarrollo. c). En los Instrumentos de Gestión y las Expropiaciones. d). En las Licencias. 4. El desequilibrio entre la obligación legal y el incumplimiento de la obligación interadministrativa de hacer efectivo el derecho a la vivienda como freno a la ejecución de la demolición de edificaciones ilegales que constituyan el domicilio habitual familiar. A. Derecho a la vivienda de los ciudadanos y deber interadministrativo. B. La protección judicial del derecho a la vivienda. 5. Las luces y sombras de la regulación penal, administrativa y de la jurisdicción Contencioso Administrativa acerca de las medidas de protección de la legalidad sobre la demolición de edificaciones ilegales. A. La obligatoriedad de la protección de la legalidad y de la reposición de la realidad física alterada. a). Sin procedimiento judicial: Sólo administrativo. b). Con procedimiento judicial firme. B. La incidencia de las modificaciones de la legisla- 
ción penal y de la jurisdicción contencioso administrativa sobre la ejecución de las sentencias sobre edificaciones ilegales. a) La modificación del art. 319 del Código Penal. b) La incidencia de la reforma de la Ley de Jurisdicción Contencioso Administrativa. i) Modificación del Recurso de Casación. ii) La reforma del art. 108.3 de la LJCA. II. LA IMPOSIBILIDAD LEGAL Y MATERIAL DE EJEGUCIÓN DE LAS SENTENCIAS. 1. Ideas Generales. 2. La imposibilidad legal. A. Delimitación y límites. B. Requisitos. 3. La imposibilidad material. III.- CONCLUSIONES.

RESUMEN: La mejora conseguida en la ejecución de las Sentencias contencioso-administrativa tiene una excepción, la ejecución de las sentencias de demolición de edificaciones ilegales. Su origen radica en algunos defectos en las legislaciones urbanísticas, y a la falta de la suficiente voluntad política municipal y autonómica, a los graves trastornos originados por la nulidad de los planes urbanísticos, consecuencia de su carácter normativo y de los efectos negativos de la impugnación indirecta y de la acción pública, estudiando para su solución una parte de la doctrina, jurisprudencia y derecho comparado; y al desequilibrio entre la obligación legal, el cumplimiento efectivo del derecho a la vivienda y a una jurisprudencia española y europea protectora de la vivienda como domicilio residencial.

Las reformas del Código Penal y, especialmente, del art.108.3 de la LJCA han dado lugar a una jurisprudencia del TS que ha concluido que no hay nuevos obstáculos para la ejecución, no se precisa resolución previa de un procedimiento de responsabilidad patrimonial y una delimitación adecuada de los terceros de buena fe. La jurisprudencia ha realizado una interpretación restrictiva de la imposibilidad legal y material del cumplimiento de las sentencias.

PALABRAS CLAVES: Ejecución Sentencias Urbanísticas. Demolición de edificaciones ilegales. Impugnación indirecta. Acción Pública. Imposibilidad legal y materia

ABSTRACT: The improvement achieved in the execution of the contentious-administrative judgments has an exception, the execution of the sentences of demolition of illegal buildings. Its origin lies in some defects in the urban legislations and to the lack of the municipal and regional political will enough; the serious disorders caused by the nullity of the urban plans, as a result of their normative nature and the negative effects of the indirect challenge and public action, studying for its solution a part of the doctrine, jurisprudence and comparative law; and the imbalance between the legal obligation and the effective accomplishment of the right to housing and a Spanish and European jurisprudence that protects housing as a residential domicile. 
The reforms of the Penal Code and, especially, of art.108.3 of the LJCA have led to a jurisprudence of the TS that has concluded that there are no new obstacles to the execution, it is not necessary to previously resolve a patrimonial responsibility procedure and a delimitation appropriate from third parties in good faith. The jurisprudence has made a restrictive interpretation of the legal and material impossibility of compliance with the judgments.

KEYWORDS: Execution of Urban Sentences. Demolition of illegal buildings. Indirect impugnment. Public Action. Legal impossibility and matter.

\section{EL ESTADO DE LA CUESTIÓN EN LA EJEGUCIÓN DE LAS SENTENGIAS URBANÍSTICAS}

\section{Factores y causas que originan la especial dificultad de ejecutar las Sentencias Urbanísticas}

Una de las cuestiones más controvertidas en el Urbanismo viene siendo la impunidad existente como consecuencia del incumplimiento generalizado de las sentencias urbanísticas. Peces Morate ${ }^{1}$ pone de relieve la insatisfacción que le produce al juez este incumplimiento de sentencias «por las Administraciones a quienes el ordenamiento jurídico impone el deber de "llevarlas a puro y debido efecto" según la expresión utilizada por la ley de la Jurisdicción Contencioso-Administrativa (Artículo 104.1)».

El régimen de ejecución de Sentencias contencioso-administrativa es una de las cuestiones más controvertidas de nuestro sistema jurisdiccional. En la Ley de Jurisdicción Contencioso Administrativa, de 27 de diciembre de 1956, en el art. 103 se establecía que "La ejecución de las Sentencias corresponderá al órgano que hubiera dictado el acto o la disposición objeto del recurso." Posteriormente la Ley de Jurisdicción Contencioso Administrativa 29/1998, de 13 de julio, (LJCA) que sustituyó la anterior, señalaba en su preámbulo VI.3 que "La Ley ha realizado un importante esfuerzo para incrementar las garantías de ejecución de las sentencias desde siempre una de las zonas grises de nuestro sistema Contencioso Administrativo. El punto de partida reside en la imperiosa obligación de cumplir las resoluciones jurídicas y colaborar en la ejecución de lo resuelto, que la Constitución prescribe y en la potestad de los órganos judiciales de hacer ejecutar lo juzgado, que la propia Constitución les atribuye".

PECES MORATE, J. E., "La Justicia en el Urbanismo y el Medio Ambiente: ¿Se cumplen las sentencias?", Revista de Derecho Urbanístico y Medio Ambiente. No 311, Madrid, Enero-Febrero 2017. 
Así, estableció en su art. 103.1 que "La potestad de hacer ejecutar las sentencias y demás resoluciones judiciales corresponde exclusivamente a los Juzgados y Tribunales de este orden jurisdiccional y su ejercicio compete al que haya conocido del asunto en primera o única instancia."

Sin embargo, lo cierto es que a pesar del importante cambio, la cuestión no se resolvió. Como acertadamente, había puesto de relieve Betancort Rodríguez": "La propia necesidad de la colaboración en todo caso de la Administración para proceder a la realización fáctica del fallo, la sitúa en una posición de ventaja que pudiera haber determinado y determina en la práctica, incluso en los sistemas judicialistas su incumplimiento por inactividad."

Lo cierto es, como señala Samano Bueno 3 , "que un buen puñado de Sentencias contrarias a la Administración Pública no se cumplen por ésta voluntariamente, pero los Jueces y Tribunales no logran ejecutarlas o lo consiguen excesivamente tarde, lo que genera un descredito social de la Administración de Justicia y provoca una tremenda frustración en los recurrentes."

Alonso Ibañez 4 cree que el panorama es desolador, pues "la realidad edificatoria revela un poder judicial que juzga pero que en demasiadas ocasiones no puede hacer ejecutar lo juzgado, donde la tutela judicial efectiva solo ampara realmente la obtención de un fallo declarativo, permaneciendo fácilmente las edificaciones ilegales."

Siguiendo estos mismos razonamientos, Peces Morate ${ }^{5}$ ponía de relieve como "a la intrascendencia de la fase probatoria se une la escandalosa inutilidad de las sentencia firmes ante hechos consumados o la renuencia a utilizar instrumentos de justicia cautelar y preventiva, que se salda después con la imposibilidad legal o material de ejecutar aquellas (artículo 105.2 de la Ley de la Jurisdicción Contenciosa Administrativa) por la pasividad de quien tiene el deber de hacerlas cumplir (artículo 104 de la misma Ley) y que para no efectuarlo, llega hasta recabar, en ocasiones, la cooperación del legislador, lo que provoca el planteamiento de cuestiones de inconstitucionalidad, con lo que el proceso se hace inacabable e inservible".

BETANCORT RODRÍGUEZ, A., "La evolución histórica normativa de la ejecución de Sentencias Contencioso Administrativas". DA No 209. Enero-Abril 1987.

3 SAMANO BUENO, P. "La ejecución de Sentencias en materia de urbanismo, repaso al estado de las cosas y alguna propuesta". RDU No 238. Diciembre 2007.

4 ALONSO IBAÑEZ, Ma . R. "La imposibilidad de ejecución de Sentencias de Demolición de Edificaciones. Medidas legales". Obra colectiva Por el Derecho y la Libertad. Libro Homenaje al Profesor Fuan Alfonso Santamaría. Iustel Madrid 2014.

5 PEGES MORATE, J. E., (2017). 
También, hace ahora algo más de 40 años, Fernández Rodríguez ${ }^{6}$ ya señalaba que el incumplimiento indirecto o el defectuoso cumplimiento de las sentencias se debe esencialmente a que la tenacidad de la Administración es muy superior a la de los Tribunales, especialmente cuando del Tribunal Supremo se trataba. Entre otras cosas, porque en aquel momento la Ley del Suelo de 1956, en su artículo 228 permitía que "si en virtud de sentencia se hubiere de desistir de la construcción o destruir alguna obra de urbanización, el Juzgado o Tribunal al que competa ejecutar el fallo lo comunicará a la Comisión Provincial de Urbanismo para que en el plazo de dos meses notifique al órgano jurisdiccional si, por motivos de interés público, se impone seguir o conservar la obras, y si no lo hiciere, se entenderá que nada obsta a la ejecución" y en caso que se dispusiera la prosecución o conservación de la obra, el Juzgado o Tribunal fijaría la indemnización que el condenado debía abonar al perjudicado.

Sin embargo, como muy posteriormente el propio Fernández Rodríguez constataba, la derogación del art. 228 de la Ley del Suelo de 1956 por la Ley de 2 de Mayo de 1975, no impidió que los Tribunales llegaran a eludir la demolición de las obras realizadas al amparo de una licencia o autorización anulada por sentencia firme cuando mediaban razones atendibles de interés público. ${ }^{7}$ Así como estableció la STC de 26 de noviembre de 1984, la inejecución de la sentencia en sus propios términos solo podrá acordarse "si el interés público que impone seguir o conservar la obra, en todo o en parte, ha de calificarse de prevalente", sobre el interés público que concurre, por ejemplo, en la defensa de los Parajes Pintorescos de Interés Nacional, prescribiendo por ello que la ejecución en sus propios términos solo puede ser sustituida mediante la realización del "juicio de prevalencia" entre los distintos intereses públicos en juego.

Por otra parte, en opinión que compartimos, para el autor anteriormente citado, la LJCA, de 13 de Julio de 1998, perfeccionó notablemente la regulación de sentencias, de tal manera "que hoy puede decirse que este asunto está razonablemente resuelto..., salvo en el ámbito urbanístico". Cabría preguntarse por tanto, ¿Cuáles son las causas que impiden que la ejecución de las sentencias urbanísticas, se lleven a cabo de manera adecuada? Existen muchas opiniones sobre el particular y se señalan muchas causas que, en mi opinión, se pueden sintetizar en las siguientes:

a) Necesidad de mecanismos preventivos y represivos eficaces ante la construcción ilegal, que atenúen los problemas políticos, sociales económicos

6 $\quad$ FERNÁNDEZ RODRÍGUEZ, T.R.. "Algunas Reflexiones sobre las formas indirectas de incumplimiento por la Administración de las Sentencias de los Tribunales de la Jurisdicción Contencioso-Administrativo". Revista de Administración Pública. No 73. Enero-Abril 1974.

FERNÁNDEZ RODRÍGUEZ, T.R., "Proceso contencioso-administrativo y urbanismo. Semejanzas y diferencias de los casos francés y español". Revista de Urbanismo y Edificación. No 29, 2013. 
y jurisdiccionales que atenazan a los gobiernos municipales a la hora de cumplir la obligación de llevar a efecto la ejecución de las sentencias.

b) La nulidad de los planes generales y los efectos perversos de la impugnación indirecta y de la acción pública.

c) El desequilibrio entre la obligación legal y el incumplimiento de la obligación interadministrativa de hacer efectivo el derecho de la vivienda como freno a la ejecución de la demolición de edificaciones ilegales que constituyan el domicilio habitual familiar.

d) Las luces y sombras de la reforma de la legislación penal y de la Jurisdicción Contencioso Administrativa acerca de la demolición de edificaciones ilegales.

\section{Mecanismos preventivos y represivos autonómicos y municipales, ante la construcción ilegal}

\section{A. Ideas Generales}

Hace algún tiempo pusimos de relieve ${ }^{8}$ que la acción municipal para evitar las edificaciones ilegales tenía que tener un carácter bifronte, por un lado a través de medidas represivas, con actuaciones ágiles de tipo inspectora (mediante planes de inspección), medidas cautelares y con una priorización de la persecución de la parcelación ilegal y la aplicación efectiva y rigurosa de las medidas de protección de la legalidad especialmente las referentes a las obras incompatibles con la ordenación y la imposición de un riguroso régimen sancionador. Pero de otro lado, era conveniente la adopción de medidas previas positivas, tales como ordenar suelo y ponerlo en el mercado a precio asequible para satisfacer la demanda de viviendas como residencia habitual para los sectores más desfavorecidos.

Estas ideas siguen pendientes de adoptarse en la dimensión debida, pues los gobierno municipales y los autonómicos, desafortunadamente, en la mayoría de los casos, por cuestiones clientelares o para no incomodar a su electorado, no adoptan eficaces medidas preventivas ni represivas inmediatas que impidan el hecho consumado. En otras ocasiones el problema radica en los adquirentes de buena fe de viviendas ilegales o en el incumplimiento del deber de los gobiernos municipales y autonómicos de hacer efectivo el derecho a la vivienda de los ciudadanos españoles y de los extranjeros a los que se lo otorguen las leyes y los Tratados. No hay que perder de vista tampoco el quebranto económico que podría llegar a ocasionar en los Ayun-

8 GUTIERREZ COLOMINA, V. "La reacción ante las urbanizaciones ilegales". Del libro Urbanizaciones de Iniciativa particular. TAL. No 22. CEMCI. Granada. 1988. 
tamientos afectados la demolición de una edificación ilegal, como consecuencia de las indemnizaciones que se puedan originar para los propietarios de buena fe.

B. Legislación autonómica de incidencia en las demoliciones de edificaciones ilegales

Como acabamos de decir, el tratamiento de las construcciones ilegales demanda dos tipos de medidas: preventivas y represivas, pero sobre todo requiere una voluntad política decidida para resolver el problema, no solo desde la Administración Local sino también desde la Autonómica. Esta última debe actuar a través de una actividad normativa que se refiera no solo a los aspectos disciplinarios, sino que contenga las bases que propicien la solución de los problemas que originan las construcciones ilegales existentes e inatacables jurídicamente. Así, mientras la Ley 4/1985 de 4 de diciembre de la CA de Madrid especial para el tratamiento de actuaciones urbanísticas ilegales en la Comunidad de Madrid contenía una regulación realista y práctica acerca de esta cuestión, la legislación cántabra y gallega, como veremos después, han supuesto una forma inadecuada y parcialmente anticonstitucional, de resolver este problema.

Puede decirse que en general la legislación autonómica no ha llevado a efecto medidas previas efectivas para evitar posteriores edificaciones ilegales. En Andalucía la LOUA sólo ha propiciado novedades en cuanto a las medidas represivas, siendo una ellas la legalización de usos y edificaciones, afectados por incumplimientos no sustanciales. El Reglamento de Disciplina Urbanística de Andalucía, (RDUA), aprobado por Decreto 60/2010, de 16 de marzo, ha desarrollado la regulación de estas medidas, incorporando la situación de asimilado al fuera de ordenación. El Decreto 2/2012 desarrolló normativamente la regulación de edificaciones y asentamientos en el SNU contra los que no pudieran adoptarse medidas de protección de la legalidad. Dentro de estas normas se contienen algunas actuaciones cautelares para evitar que nos encontremos ante el hecho consumado que impida llevar adelante la restauración del orden urbanístico. De entre todas las anteriores cuestiones merecen destacarse por su relevancia, la agilidad para resolver los expedientes de protección de la legalidad de las obras manifiestamente incompatibles con la Ordenación y la regulación de las parcelaciones ilegales.

C. Reposición exprés de la realidad física alterada por obras manifiestamente incompatibles con la Ordenación Urbanísticas

En lo referente a la primera medida, la agilidad para resolver la restauración del orden urbanístico, conviene decir que aunque las obras no sean compatibles con la ordenación, el previo expediente de legalización siempre es necesario, según la jurisprudencia, salvo cuando sea clara la ilegalidad e improcedente la obra cuya demolición se pretende (Ss. TS 30 de Enero de 1985, 26 de Febrero y 28 de Marzo de 1988 
y 29 de Octubre de 2004). Hemos defendido desde hace algún tiempo la oportunidad y eficacia de este procedimiento ${ }^{9}$ ya que "desde el punto de vista del sentido común, parece ilógico la concesión del plazo de legalización de los dos meses cuando nos encontramos con una infracción claramente ilegalizable, como según queda dicho, normalmente ocurre en el suelo no urbanizable." Y a tal efecto señalábamos que nos parecía loable la interpretación jurisprudencial de la Sentencia del Tribunal Supremo de 30 de enero de 1985 que decía que: "No se causó indefensión al demandante al no darle el plazo de dos meses para que regularizara las obras efectuadas pues estas efectivamente no lo son".

La legislación autonómica también fue incorporando una regulación que resolvía lo anterior de la misma manera. Así, el art. 207.a) de la Ley 2/2001, de 25 de junio de Ordenación Territorial y Régimen Urbanístico de Suelo de Cantabria, estableció que sin perjuicio del expediente sancionador, "si las obras fueran incompatibles con el planeamiento vigente decretará su demolición, reconstrucción o cesación definitiva a costa del interesado." El art. 118.a) de la Ley 5/1999, de 8 de abril, de Urbanismo de Castilla y León igualmente establece, que con independencia de las sanciones, el Ayuntamiento resolverá: "si los actos sancionados fuesen incompatibles con el planeamiento urbanístico su definitiva suspensión, con demolición o reconstrucción de las construcciones e instalaciones que se hubieran ejecutado o demolido, respectivamente a costa de los responsables." En sentido similar se regula en el art. 211.1 a) de la Ley 5/2006 de Ordenación del Territorio y Urbanismo de la Rioja, y en el art. 202 a) del Texto Refundido de la Ley Foral de Ordenación del Territorio y Urbanismo de Navarra. (DL 1/2017, de 26 de Julio).

En Andalucía se contiene en el art.183 a) de la Ley 7/2002, de 17 de diciembre, de Ordenación Urbanística de Andalucía (LOUA), previéndose para las actuaciones de urbanización o edificación que sean manifiestamente incompatibles con la ordenación urbanística. El art. 52 del RDUA señala que el Ayuntamiento o la Consejería, dispondrán la inmediata demolición de las actuaciones de urbanización o edificación que sean manifiestamente incompatibles con la ordenación urbanística, previa audiencia del interesado, en el plazo máximo de un mes. En el apartado 2 del artículo, recoge las actuaciones que son manifiestamente incompatibles con la ordenación urbanística, como son los siguientes:

- Cuando exista una previa resolución administrativa denegatoria de la licencia para la ejecución de las obras objeto del procedimiento.

Vid del Autor Régimen jurídico urbanístico del espacio rural: la utilización edificatoria del suelo no urbanizable. Editorial Montecorvo, S.A. Madrid 1990. Pág. 254. 
- Cuando la ilegalidad de las obras o edificaciones resulte evidente de la propia clasificación o calificación urbanística y, en cualquier caso, las actuaciones de parcelación o urbanización sobre suelos no urbanizables, y cualesquiera otras que se desarrollen sobre terrenos destinados por el planeamiento a sistemas generales o dotaciones públicas.

- En los supuestos de actos sujetos a licencia urbanística realizados sobre terrenos de dominio público sin haber obtenido previamente la correspondiente concesión o autorización demanial.

Se establece un procedimiento ágil y exprés, en el que el acuerdo de inicio tendrá que declarar la causa de incompatibilidad manifiesta con la ordenación urbanística y estar precedido de informes técnico y jurídico que la fundamenten. De dicho acuerdo se concederá audiencia a los interesados por un plazo entre 10 y 15 días. La resolución acordando la demolición de las actuaciones de urbanización o edificación se dictará antes del transcurso del plazo de un mes desde que se haya producido la notificación del acuerdo inicio del procedimiento. Si no se llevase a cabo por el interesado el cumplimiento de la Resolución en el plazo fijado, se prevé como medio de ejecución forzosa solo la ejecución subsidiaria, excluyéndose expresamente la imposición de medidas coercitivas. Es indudable, que esta regulación le ofrece la posibilidad a la Administración municipal de actuar rápidamente para impedir el hecho consumado, pero requiere una auténtica voluntad política, lo que desgraciadamente no ocurre en la práctica. Es necesario tener previsto en la organización municipal una unidad que gestione la disciplina urbanística y que actúe con rapidez y profesionalidad, así como disponer de medios operativos internos o externos, es decir, a través de una empresa que gestione las demoliciones, que pueda actuar con la debida inmediatez. Nos parece por ello muy acertado, que solo se permita en este supuesto la ejecución subsidiaria y no la multa coercitiva, que solo tiene en el ámbito del urbanismo un cómodo objetivo meramente recaudatorio pero que no suele servir para la efectiva restauración de la legalidad urbanística.

\section{Las parcelaciones ilegales en el SNU}

En Andalucía, el Decreto 2/2012, de 10 de Enero, por el que se regula el régimen de las edificaciones y asentamientos existentes en el suelo no urbanizable, establece que se adoptarán las medidas que procedan para el restablecimiento de la legalidad urbanística y del orden jurídico infringido sobre éstos. Aunque debe tenerse en cuenta que la no caducidad de la acción para restaurar el orden urbanístico en una parcelación ilegal en SNU, fue incorporada por la LOUA y por tanto, como es obvio, pueden existir estos asentamientos con anterioridad a la vigencia de ésta y puede por ello haber caducado, en ese caso, la acción de protección de la legalidad. 
Como decíamos ${ }^{10}$ no regía la limitación temporal de los cuatro años (actualmente de seis años) desde la terminación de la parcelación ilegal en el SNU para la reposición de la realidad física alterada, que era, sin embargo, de aplicación a las edificaciones ilegales en el SNU que no fuese de especial protección, para las que si contaba el plazo de seis años (art. 185.4 LOUA), para restaurar la legalidad.

Por ello, alertábamos que se podía producir una auténtica disfunción sobre la legalización o no de la actuación, en el caso, que transcurrieran seis años desde la construcción de una edificación ilegal y se hubiera producido una parcelación ilegal también, en un SNU común. Porque en ese caso, en nuestra opinión, había caducado la acción para restaurar el orden urbanístico en lo referente a las edificaciones ilegales, si el SNU no era protegido, pero no habría caducado la acción para poner fin a la parcelación ilegal, por lo que pensábamos que para conciliar ambas situaciones, solo era posible la protección de la legalidad mediante la reagrupación en una parcela indivisible de todas las parcelaciones existentes y de las edificaciones existentes bajo el régimen de propiedad horizontal o conjunto inmobiliario de acuerdo con el art. 82 del RD 1093/1997.

Sin embargo, el desarrollo reglamentario de Andalucía no siguió el planteamiento indicado, sino que el artículo 49.2 RDUA estableció, que la resolución que pusiera fin al procedimiento de reposición de la realidad física alterada, en el caso de parcelaciones ilegales en el SNU, debería adoptar las siguientes medidas:

En el caso de parcelaciones urbanísticas en terrenos que tengan el régimen del suelo no urbanizable, el restablecimiento del orden jurídico perturbado se llevará a cabo mediante la demolición de las edificaciones que la integren y reagrupación de las parcelas, a través de una reparcelación forzosa de las que han sido objeto de dichos actos de previa parcelación".

Partiendo de un distinto enfoque normativo al del RDUA, se aprobó en el Parlamento de Andalucía la Ley 6/2016, de 1 de agosto, por la que se modificaba la LOUA para incorporar medidas urgentes en relación con las edificaciones construidas sobre parcelaciones urbanísticas en suelo no urbanizable.

Como decíamos ${ }^{11}$, esta Ley de modificación de la LOUA, era verdaderamente una amnistía encubierta para unas determinadas edificaciones ilegales, porque sólo venía a resolver el problema de las edificaciones ilegales existentes dentro de una

$10 \quad$ Vid del autor "Comentarios al art. 21.4 de la LOUA sobre parcelaciones en terrenos que tengan el régimen del suelo no urbanizable. Pág. 1529 del libro Comentarios a la Ley de Ordenación Urbanística de Andalucía, codirigido por GUTIERREZ COLOMINA, V. y CABRAL GONZÁLEZ-SICILIA, A. Ed. Thomson. Aranzadi. Pamplona 2007. Y Urbanismo y Territorio en Andalucía $3^{\text {a }}$ Edición. Thomson Aranzadi. 2012.

11 Vid del Autor. "Los efectos de la nulidad de los Planes Urbanísticos en Andalucía y su repercusión en las edificaciones ilegales." Revista Andaluza de Administración Pública. No 96, 2016. 
parcelación ilegal, para las que hubiera pasado el plazo de 6 años siguientes a su completa terminación, pero no resolvía, por ejemplo, el problema de las edificaciones ilegales en los Suelos No Urbanizables calificados de Protección Territorial en los Planes Subregionales de Ordenación del Territorio de Andalucía, que propiamente no tienen unos valores que conlleven una específica protección, y por ello, sin una adecuada fundamentación ${ }^{12}$, le otorgan un indebido carácter de especial protección, por lo que la acción para restaurar el orden urbanístico y la consiguiente demolición, en este caso no caducara nunca, y salvo que se flexibilice en los Planes de Ordenación Territorial esta "singular especial protección", permitiendo determinados usos residenciales existentes, la modificación de la LOUA por la Ley 6/2016, no habrá servido para resolver esta cuestión. En efecto, según el apartado tres de su artículo único esta excepción de limitación temporal de la caducidad de la protección de la legalidad, únicamente será de aplicación a la parcela concreta sobre la que se encuentre la edificación en la que concurran los citados requisitos, no comprendiendo al resto de parcela o parcelas objeto de la parcelación. No se arbitra un procedimiento, proporcionado para la reposición física de las parcelaciones ilegales existentes y futuras, puesto que es indudable que desafortunadamente se van a seguir produciendo, y la subsistencia de la regulación del art.49.2 j que comporta la restauración del orden urbanístico, a través de la demolición y la reagrupación de parcelas, no va a ser fácil de llevar a cabo en la práctica, y va a producirse un agravio comparativo con las "amnistiadas" por la Ley 6/2016

\section{La nulidad de los planes urbanísticos y los efectos perversos de la impugnación indirecta y de la acción pública}

A. Punto de partida: Naturaleza jurídica de Disposición General

Desde la aprobación de la Ley de Jurisdicción Contencioso-Administrativo de 27 de diciembre de 1956 y de las leyes del suelo de 1956 y posteriormente la de 1975 (Texto Refundido de 1976) surgió un amplio debate sobre la naturaleza jurídica de los planes generales como reglamento o acto administrativo de carácter general, que concluyó en que la mayor parte de la doctrina y sobre todo la doctrina jurisprudencial del Tribunal Supremo, de manera mayoritaria, le atribuye a los Planes ur-

12 Estos Planes no tienen en cuenta el carácter reglado del SNU de especial protección, reconocido por la doctrina jurisprudencial. Así, por ejemplo, la STSJ de Andalucía, de 10 de febrero de 2016, anula en el POTAUM la clasificación como SNU de especial protección de determinadas fincas puesto que están en terrenos que carecen de riesgo de inundabilidad, erosión, condiciones ecológicas ambientales y paisajísticas, que merezcan dicha protección.

13 Prueba de cuanto decimos, es la última modificación por ahora de esta Ley, aprobada por el Parlamento el 11 de abril de 2018, extendiendo la autorización provisional para acceder a servicios básicos no solo a las viviendas aisladas sino a las que formen parte de determinados asentamientos. 
banísticos la naturaleza de Reglamento. Ello ha comportado que cualquier tipo de defecto jurídico en su tramitación o contenido, provenga de una infracción formal o sustantiva, provoca la nulidad de pleno derecho, de acuerdo con lo que disponía el art. 62.2 de la LRJPAC, para el que eran nulas de pleno derecho las disposiciones administrativas. Tampoco cambia dicha situación con la entrada en vigor de la Ley 39/2015, de 1 de Octubre, puesto que mantiene la misma regulación en su artículo 47.2. Esta nulidad radical de pleno derecho comporta la imposibilidad de subsanación, convalidación o conservación de trámites, así como la no admisión de la "retroacción de actuaciones al momento procedimental en que se cometió el error"14 y la imposibilidad de interposición de recurso de reposición de acuerdo con lo que decía el art. 107.3 de la LRJPAC, que se regula de la misma forma en el art. 112.3 de la Ley 39/2015. No obstante, como señala Agoúes Mendizábal ${ }^{15}$ el art. 50 TRLS08 (actual 64.2 TRLSRU) hace una remisión al legislador autonómico para que éste pueda regular los posibles recursos administrativos frente a los actos de aprobación definitiva de los planes urbanísticos y de ordenación territorial. Lo que ha originado que determinadas legislaciones autonómicas obliguen a la interposición del recurso de alzada contra el acto de aprobación definitiva de los planes para acudir a la vía judicial contenciosa - administrativa. Así el art. 16.4 del Derecho Legislativo 1/2010, de 3 de Agosto que aprueba el Texto Refundido de la Ley de Urbanismo de Cataluña establece "Contra los actos y acuerdos, expresos o presuntos, de las comisiones territoriales de urbanismo y del director o directora general de Urbanismo, incluidos los relativos a las resoluciones definitivas sobre planes y otros instrumentos urbanísticos, se puede interponer recurso de alzada ante el consejero o consejera de Política Territorial y Obras Públicas. Contra los actos y acuerdos del consejero o consejera de Política Territorial y Obras Públicas y los del Gobierno de la Generalidad, se puede interponer recurso potestativo de reposición previo a la vía contencioso-administrativa." Igualmente el art. 13 del Decreto 163/2003, de 18 de septiembre de Cantabria establece que los acuerdos de la Comisión Regional de Ordenación del Territorio y Urbanismo serán recurribles en alzada ante el Consejo de Gobierno, según el art. 5.2.h), entre otros acuerdos "aprobar definitivamente los Planes Generales de Ordenación Urbana".

14 De COMINGES CÁCERES, F. "Los efectos de la anulación judicial de un Plan General. La necesaria modulación de la equiparación de Planes Urbanísticos y Disposiciones Reglamentarias. Propuestas de Mejora del Sistema". RDU. Núm. 314. Madrid, junio 2017.

15 AGOÚES MENDIZÁBAL, G., "Reflexiones sobre el alcance del Recurso indirecto contra Reglamento en relación con los planes urbanísticos". RAP. No 190. Madrid Enero-Abril 2013. 


\section{B. La impugnación indirecta del Planeamiento}

Como establece el art. 26.1 de la LJCA, además de las impugnaciones directas de disposiciones de carácter general, también es admisible la de actos que se produzcan en aplicación de estas, fundadas en que tales disposiciones no son conforme a Derecho. Pero esta norma que tuvo en su origen una finalidad garantista de la legalidad, ha comportado en la práctica, en muchos casos, una consecuencia "perversa", en su aplicación a la impugnación indirecta del plan urbanístico, como es que en cualquier momento, sin límite de tiempo, está abierta la posibilidad de que se produzca la nulidad de un plan urbanístico, siempre que haya una relación de causalidad entre las imputaciones de ilegalidad de la norma y de disconformidad con el acto de aplicación, o incluso a través de un recurso directo contra un Plan de desarrollo ${ }^{16}$ que también produce un efecto indirecto contra el Plan General, dando lugar a lo que Casanova Gómez ${ }^{17}$ llama "la perpetua interinidad del planeamiento General en nuestro país." El Tribunal Supremo, ha señalado por ello, que aunque la LJCA no excluye la impugnación de vicio alguno por esta vía indirecta, no se puede "transformar la impugnación indirecta de los reglamentos en un procedimiento abstracto de control de normas permanentemente abierto y con independencia de que el vicio advertido se proyectase o no sobre el acto concreto de aplicación, como sucedería si a través de la impugnación indirecta se pudiesen plantear los vicios formales o de procedimiento en que pudiera haber incurrido la elaboración de una disposición reglamentaria. Por lo contrario, la impugnación de los vicios de procedimiento tiene su sede natural en los recursos directos y en los plazos para ellos establecidos, quedando el recurso indirecto tan solo para depurar con ocasión de su aplicación los vicios de ilegalidad material en que pudieran incurrir las disposiciones reglamentarias y que afecten a los actos de aplicación directamente impugnados.”(STS 26 de diciembre 2011. Recurso de Casación 2124/2008).

\section{La acción pública}

Basada en el derecho a la tutela judicial efectiva, en el urbanismo se instauró la acción pública. En virtud de la acción pública se atribuye a cualquier persona la legitimidad para exigir la observancia del ordenamiento urbanístico, sin necesidad de ser titular de ningún derecho subjetivo, ni de interés alguno, que no sea el interés de la mera defensa de la legalidad (STS de 24 de enero de 2001, Sala $3^{\text {a }}$ R/2001/632).

Los Tribunales han sido reticentes a limitar el ejercicio de la acción pública por un supuesto ejercicio abusivo, entendiendo que la finalidad prevalente y fundamental de ella, es la de procurar el cumplimiento de la legislación urbanística y del planea-

16 AGOUES MENDIZÁBAL, C., (2013).

17 CASANOVA GÓMEZ, C., "La restauración del Plan General de Ordenación Urbana de Madrid tras su anulación parcial por resoluciones judiciales o la perpetua interinidad del Planeamiento General en nuestro país.” RDU. No 287. Enero-Febrero 2014. 
miento urbanístico, ahora también territorial, aunque sus razones sean "represalia de actuaciones anteriores, tal como sostiene el recurrente, son irrelevantes frente a los fines prevalentes de protección y observancia del ordenamiento urbanístico, en su concreta aplicación" (STS 29 de enero de 2002).

Lo anterior, ha originado que la acción pública se haya utilizado de una manera abusiva, contraria para lo que estaba pensado, de ahí, que Fernández Rodríguez, ${ }^{18}$ con el fin de "poner coto a los recursos abusivos en España después de más de medio siglo de experiencia," haya señalado que "no hay más remedio que suprimir la acción pública."

D. La distinción entre los actos de tramitación del Plan y el Plan en sí

Es indudable por tanto que con lo laborioso y complicado que es el procedimiento de tramitación de un PGOU, su nulidad arrastra unas consecuencias bastantes traumáticas. Y puede hacerse como hemos dicho al cabo de mucho tiempo puesto que no existe plazo alguno, si acudimos a la impugnación indirecta a través de un acto de aplicación, como ha ocurrido con Planes Generales como el de Madrid, anulado después de más de 15 años. Son innumerables los Planes anulados en los últimos tiempos, entre los que destacan, además del de Madrid, el de Ourense, Zamora, Toledo, Ávila, Castellón, Gijón y Marbella. Y la forma de remediarlo los efectos de esta anulación no suele ser fácil, puesto que como hemos dicho, hay que volver a iniciar la tramitación desde el principio. Aunque existen algunas posturas autorizadas que intentan apuntar hacia una atenuación de esa nulidad radical. Entre otros, Santamaría Pastor ${ }^{19}$ considera que puede hablarse de una auténtica plaga, que está provocando en los últimos tiempos, una considerable anulación de instrumentos de planeamiento, especialmente de planes generales y considera que parece difícilmente sostenible "conferir una calificación única a un amplio complejo documental, "el plan", cuyo contenido es manifiestamente heterogéneo, y buena parte del cual carece con absoluta evidencia de todo contenido normativo." Por ello entiende que la imposibilidad de la de la convalidación no afecta más que a los trámites irregulares, pero que esto debe ser contemplado con lo dispuesto en lo referente a los trámites realizados conforme a Derecho, es decir "aquellos actos y trámites cuyo contenido se hubiera mantenido igual de no haberse cometido la infracción” (actualmente regu-

18 FERNÁNDEZ RODRÍGUEZ, T.R., "Proceso contencioso - administrativo y urbanismo. Semejanzas y diferencias de los casos francés y español". Revista de Urbanismo y Edificación. N 20, 2013.

19 Véase SANTAMARÍA PASTOR, J. A. "Muerte y transformación de la desviación de poder: Sobre las sentencias anulatorias de Planes Urbanísticos", RAP. No195, 2014 y "Los Proyectos de Ley del Procedimiento Administrativo Común de las Administraciones Públicas de Régimen Jurídico del Sector Público: Una primera Evaluación", D.A. N 2 Enero-Diciembre 2015 y RENAU FAUBELL, F., "La nulidad "radiactiva" de los planes urbanísticos por defectos en el procedimiento de aprobación". Noticias Jurídicas 10-3-2016. 
lado en el art. 51 LPAG), puesto que "esta conservación no puede ser eludida con el pretexto de que el plan es un reglamento y que está viciado de nulidad" ya que el art. 51 debe ser aplicado "tanto cuando el acto final es anulable como cuando es nulo" porque "no se refiere solo a los actos administrativos, sino a todo tipo de "actuaciones administrativas". En el mismo sentido De Cominges Cácere ${ }^{20}$ subraya que de todos los documentos del plan, solo las ordenanzas tienen carácter normativo indubitado.

Parejo Alonso ${ }^{21}$ pone de relieve el necesario reconocimiento de la singularidad del plan "como proceso decisional y matizándola en función de la peculiaridad, complejidad y diversidad del contenido y el alcance de los instrumentos de ordenación territorial urbanística", llegando como consecuencia a la diferenciación de la impugnación de los actos de tramitación y aprobación por un lado, y de otro, la de los planes. Siendo a efectos del control judicial de la tramitación y aprobación de los planes, el régimen de los actos administrativos. Y la aplicación del régimen de las disposiciones administrativas para los planes mismos ${ }^{22}$.

El art. 64.2 del TRLSRU abona esta misma distinción entre los actos de tramitación y el Plan en sí, puesto que establece que "Los actos de aprobación definitiva de los instrumentos de ordenación territorial y de los de ordenación y ejecución urbanísticas, sin perjuicio de los recursos administrativos que puedan proceder, podrán ser impugnados ante la jurisdicción contencioso-administrativa, en los términos prevenidos por su legislación reguladora".

También hay alguna legislación en derecho comparado que transita por un camino similar para abordar esta cuestión ${ }^{23}$.

Desde la perspectiva jurisprudencial es conveniente resaltar por su interés sobre la cuestión que comentamos, la Sentencia del Tribunal Supremo de 9 de diciembre de 2008, RJ 2009/458, referida al recurso contencioso-administrativo in-

20 De COMINGES CÁCERES, F., (2017)

21 PAREJO ALFONSO, L., "El plan urbanístico no es solo norma. En pro de la superación de la doctrina simplificadora de su naturaleza”, Práctica Urbanística. $\mathrm{N}^{\circ}$ 144, Sección Estudios. Editorial Wolters Kluwer. La Ley 9895/2016.

22 En esta línea, de distinguir entre defectos que provoquen la nulidad y anulabilidad de los Planes, parecía ir un anteproyecto de ley que ultimaba el Ministerio de Fomento, según lo manifestado en la comparecencia para informar del Plan Estatal de Vivienda 2018/2021, efectuada ante la Comisión de Fomento del Congreso.

${ }_{23}$ Véase el nuevo artículo L-600-9 del Código urbanístico francés. La ley francesa No 2014-366, de 24 de marzo de 2014, ley para el acceso a la vivienda y un urbanismo renovado, introdujo en el Código Urbanístico francés el nuevo artículo L600-9. En la redacción vigente, establecida por la Ordenanza $\mathrm{N}^{\circ}$ 2015-1174, de 23 de septiembre de 2015, posibilita al juez administrativo que conoce un recurso interpuesto contra un plan urbanístico, en el caso que el motivo alegado sea un vicio de procedimiento, puede subsanar ese defecto. Durante este plazo de subsanación el plan recurrido sigue en vigor. Subsanado por la Administración el defecto de procedimiento, el Tribunal resolverá el recurso. 
terpuesto contra una Resolución de la Consellería de Obras Públicas, Urbanismo y Transportes de la Generalitat Valenciana, de 1 de Marzo de 2000, por la que se aprueba definitivamente la revisión del PGOU de Castellón, acuerda la necesidad de sometimiento a un nuevo trámite de información pública, a la vista de las modificaciones sustanciales introducidas con relación al documento aprobado inicialmente, estableciendo en su Fundamento de Derecho, que al ser la razón de la estimación del recurso de índole formal o procedimental, procede "ordenar la retroacción del procedimiento administrativo al momento inmediatamente posterior al acuerdo de aprobación provisional, para su sometimiento a un nuevo trámite de información pública a la vista de las modificaciones sustanciales introducidas con relación al documento aprobado inicialmente."

En la misma línea, la STS de 20 de Septiembre de 2012, RJ 2012/9755, a propósito de la declaración de nulidad del Plan General de Parets del Vallés, por no haberse vuelto a sacar a nueva información pública, antes de la aprobación provisional, por haberse producido modificaciones sustanciales y en contestación a las alegaciones efectuadas sobre la necesidad de llevar a cabo una nueva tramitación del planeamiento desde el principio. El TS señaló que "no se puede permitir confundir lo que es la nulidad de planeamiento urbanístico por falta de haber agotado la tramitación preceptiva para equipararla a la nulidad de todos los trámites producidos en el procedimiento administrativo de su razón”. Deja claro que no era necesaria una nueva aprobación inicial del planeamiento general y que no debe producirse un acuerdo de convalidación, sino que estamos ante nuevas actuaciones, como son la información pública, la nueva aprobación provisional por el Ayuntamiento y la aprobación definitiva "que tienen valor por si mismas".

Por otra parte la STS de 31 de octubre de 2014 recoge una jurisprudencia que ha declarado en más de una ocasión (SS TS 4-7-00, 21-6-00, 23-7-99, 27-5-99 y 22-11-94) que "existen determinaciones dentro de los planes urbanísticos que carecen de los elementos necesarios que permiten calificarlas como verdaderas normas o disposiciones administrativas de carácter general, y que no son sino actos administrativos singulares al ser concretos y determinados sus destinatario y su vigencia no indefinida sino referida a un concreto periodo de ejecución" También el TSJ de Cataluña, en sentencia de 1 de Marzo de 2011 ha mantenido que "Los preceptos de la legislación urbanística catalana en los que regula el procedimiento de aprobación de los planes deben ser interpretados concordante con el citado artículo 107.3 de la Ley 30/92, pues si cabe una interpretación armonizadora debe aceptarse para evitar el desplazamiento que la prevalencia de Ley básica estatal producirá en otra caso sobre la norma autonómica. (Artículo 149.3 de la G.E.)." Y como consecuencia "El acuerdo de aprobación definitiva de un Plan de Urbanismo tiene un aspecto de acto administrativo (el acuerdo en sí adoptado por la Comisión, con sus requisitos de 
procedimiento, de quórum, etc.) y otro aspecto de disposición de carácter general (el propio Plan de urbanismo que se aprueba). Pues bien, la exigencia de agotamiento de la vía administrativa que imponen en el Derecho Autonómico de Cataluña los artículos 294 del TR 1/90, de 12 de Julio y 16.4 de la Ley Autonómica 2/2002, de 14 de marzo, es conforme a Derecho en cuanto se impugne el acuerdo de la Comisión en el aspecto que tiene de acto administrativo, pero no en cuanto se impugne la disposición misma, pues en este último caso el artículo 107.3 de la Ley 30/92 prohíbe la alzada".

No obstante, hay que tener en cuenta que la STS de 25 de mayo de 2015, RJ2015/2712, establece que en lo relativo a la jurisprudencia acerca de los efectos de la nulidad de un plan urbanístico como consecuencia de la omisión de algún trámite relevante en el curso del procedimientos conducente a su aprobación, no cabe proceder sin más a la mera reposición del trámite omitido, en el caso que los presupuestos normativos hayan cambiado. Así pues a sensu contrario, si los presupuestos normativos no han cambiado, no habrá problema en retrotraer el expediente al momento en que se produjo la omisión del informe. En mi opinión, a la misma conclusión habría de llegarse, si el cambio normativo no fuera sustancial.

\section{E. Efectos de la nulidad del Planeamiento}

a) Efectos generales

Las Sentencias firmes que anulen un precepto de una disposición general no afectan por si misma a la eficacia de las sentencias o actos administrativos firmes que lo hayan aplicado antes que la anulación alcanzara efectos generales, salvo que como señala el art. 73 de la LJCA, el precepto suponga la exclusión o reducción de sanciones no ejecutadas completamente. De la misma manera, el art. 64.1 LRJPAC (derogado) señalaba que la nulidad o anulabilidad de un acto no implicará la de los sucesivos en el procedimiento que sean independientes del primero.(La misma redacción tiene el art. 49.1 de la LPAC, que lo ha sustituido). En el mismo sentido, el art. 40.1 de la Ley 2383/1979 Orgánica del Tribunal Constitucional. Por tanto se produce la subsistencia de los actos firmes dictados en aplicación de la disposición general declarada nula, equiparando, como señala Sánchez Goyanes²4, "la anulación o la derogación, en que los efectos son "ex nunc" y no "ex tunc", si bien sólo respecto de los actos firmes, permaneciendo en cuanto a los no firmes la posibilidad de impugnarlos en función del ordenamiento jurídico aplicable, una vez declarada nula la disposición general".

24 SÁNCHEZ GOYANES, E., "Extinción jurídica de un plan y supervivencia de sus actos derivados: uniformidad en la diversidad jurisprudencial". Práctica Urbanística. N 106, Sección Estudios, Julio 2011. Pag 16 Ed. La Ley. 


\section{b) Efectos en el Planeamiento de Desarrollo}

La nulidad del Plan General de Ordenación Urbanística provoca también la nulidad del Planeamiento secundario. En efecto la STS de 28 de septiembre de 2012, recurso de casación 1009/2011 señala que "los efectos propios de la nulidad plena impiden igualmente que el ordenamiento derivado, planes parciales y de sectorización, puedan tener cobertura en las concretas normas declaradas nulas, como venimos señalando de modo profuso y uniforme en el ámbito urbanístico". La Sentencia TS, de 19 de junio de 2013, RJ2013/5629, igualmente señala que en el caso de la anulación del planeamiento general, el fallo declarativo tiene un efecto expansivo derivado de la exigencia de la realización completa del fallo sobre el planeamiento secundario, con independencia de si su aprobación hubiese sido anterior a la sentencia anulatoria. La efectiva realización del fallo puede comportar la invalidación de determinados actos o disposiciones, lo que requerirá seguir "el trámite previsto en el art. 109 LJCA.” En este sentido es aconsejable recordar que el art. 104.1 de la LJCA habilita con evidente amplitud al órgano jurisdiccional competente para la ejecución de la sentencia con la finalidad de que se "practique lo que exija el cumplimiento de las declaraciones contenidas en el fallo."

Existen otras figuras urbanísticas, acerca de las que no es pacífica su consideración como planes urbanísticos. Un ejemplo de lo anterior, sucede en los supuestos en los que se atribuye mediante un determinado procedimiento de declaración de utilidad pública o interés social (calificación, actuaciones de interés pública o declaración de intereses comunitarios) un determinado aprovechamiento del Suelo No Urbanizable. Según Blanquer ${ }^{25}$ la calificación urbanística para lo que él llama actuaciones "impropias" en el suelo rústico, aunque "sea un simple acto habilitante y no tenga la naturaleza normativa que es propia de los instrumentos de planeamiento, lo cierto es que en alguna medida cumple una función parecida o similar a la de un plan especial", pero "no es un auténtico plan urbanístico, aunque puede parecerlo", y por ello reconoce que en la Comunidad Valenciana, la declaración de interés comunitario se precisa cuando no exista planificación del suelo rústico (Art. 202.2 Ley 5/2014), de 25 de julio, de Ordenación del Territorio, Urbanismo y Paisaje de la Comunidad Valenciana.

En mi opinión, este instrumento de calificación del aprovechamiento en suelo rústico desde su propio arranque tenía carácter reglamentario ${ }^{26}$. Así, como decíamos, el art. 85 del TRLS76 remitía al procedimiento de un Plan Especial simpli-

\footnotetext{
25 BLANQUER, D., "Espacios de discrecionalidad en las licencias urbanísticas." Del libro El Derecho de la Ciudad y el Territorio. Estudio en Homenaje a Manuel Ballbé Prunés. INAP, 2016.

26 Véase del Autor, Régimen Furídico Urbanístico del especio rural. La utilización edificatoria del Suelo no urbanizable. Editorial Montecorvo 1990 Madrid.
} 
ficado regulado en el art. 43.3 de la misma norma. En la regulación andaluza, en el art. 42 de la LOUA se utiliza, según los supuestos, su calificación a través de un Plan Especial o Proyecto de Actuación sin que se establezca diferencia de contenido entre ambos. Sin embargo existe cierta confusión jurisprudencial sobre la naturaleza jurídica del proyecto de actuación. Así la STSJ de Andalucía de 16 de febrero de 2015 señala que "la ejecución de una sentencia que anula un Proyecto de Actuación extiende sus efectos a todas las licencias que pudieran traer causa de la actuación anulada". No parece muy acertado lo establecido en esta sentencia, determinando la anulación automática de la licencia, sin entrar a valorar si el proyecto de actuación tiene el carácter de Disposición General, en cuyo caso no procedería la anulación de la licencia, si había alcanzado firmeza. O si tiene carácter de acto administrativo, en cuyo caso como opina García Tejada debería acudirse a la revisión de oficio para la anulación de la licencia ${ }^{27}$.

\section{c) En los Instrumentos de Gestión y las Expropiaciones}

Según la anterior Sentencia del TS de 19 de junio de 2013, "es distinto lo que ocurre con los instrumentos de gestión, porque no tienen la consideración de disposiciones generales", por tanto, aunque haya desaparecido su presupuesto legitimador la existencia de un Plan previo del que dependa, esto no produce la nulidad automática de los instrumentos aprobatorios de la gestión, sino que para acordarla, habrá de seguirse el trámite del art. 109 de la Ley Jurisdicción Contencioso Administrativa con audiencia de las personas que puedan verse afectadas por la ejecución, singularmente las entidades urbanísticas".

En efecto, como dice De Comingues Cáceres ${ }^{28}$, "para salvaguardar el principio de seguridad jurídica y proteger los intereses públicos, desde tiempo atrás la jurisprudencia ha venido moderando la aplicación del referido axioma del contagio retroactivo de la nulidad de la disposición general a sus actos de aplicación, en el sentido de "inmunizar" a los que hubiesen devenido firmes antes de la declaración de nulidad de aquella".

La jurisprudencia se refería en principio a las liquidaciones firmes de carácter tributario o análogo, en base a un reglamento declarado nulo, se extendió después posteriormente a todas las ramas del derecho administrativo. Actualmente viene regulado en el art. 73 de la LJCA y 106.4 de la LPAC.

27 GARCíA TEJADA, D. J., "La ejecución de sentencias en la anulación de Proyectos de Actuación en suelo no urbanizable". El Consultor de los Ayuntamientos. No 2, Sección Urbanismo y Medio Ambiente, febrero 2018, editorial Wolters Kluwer.

28 COMINGES GÁCERES, F., (2017). 
Con la Sentencia del Tribunal Supremo, de 12 de noviembre de 2010, RJ 2010/829, pareció que se había producido un cambio en la anterior doctrina jurisprudencial pues distinguió entre actos de aplicación y actos de ejecución urbanística, considerando que los actos de aprobación y constitución de los Estatutos de la Junta de Compensación, así como los Proyectos de Urbanización y Reparcelación, no podían ser considerados como "meros actos de aplicación de una disposición general sino que añaden una cualidad superior, que son actos dictados en ejecución del propio Plan Parcial declarado nulo." Conviene señalar, no obstante, que se partía de la anulación de un Plan Parcial porque no se había citado personalmente para la información pública a los propietarios de terrenos y que por ello, lo establecido en la Sentencia comentada era consecuencia de la necesidad de proteger la indefensión que se había generado a los propietarios ${ }^{29}$ y que se reproducía, por tanto, en los actos de gestión en aplicación del planeamiento. Por ello, coincidimos con Plaza González ${ }^{30}$ que en esta Sentencia de 12 de noviembre de 2010 "no se ha establecido una nueva doctrina con vocación de generalidad, en virtud de la cual se exceptúe la aplicación del art. 73 de la LJCA a todos los actos de gestión urbanística." Prueba de lo anterior es lo que recoge la STS, de 12 de marzo 2015, RJ 2015/3626, de que no resulta de aplicación la STS de 12 de noviembre de 2010, porque no se trata de un supuesto equivalente, es decir, no existe un problema de indefensión de los propietarios y porque lo que procede es preservar la firmeza alcanzada por los actos administrativos. "Porque no tienen la consideración de disposiciones generales." Y además "la indefinición de la nulidad que se propugna menoscabaría elementales exigencias del principio de seguridad jurídica”.

Aunque conviene señalar que en lo referente a la Expropiación Forzosa el criterio que mantiene el Tribunal Supremo es distinto. Así, establece la STS de 5 de Septiembre de 2015, recurso 3.003/2013, que es doctrina del TS (Ss 19 de Mayo y 6 de Junio de 1992, 11 de Noviembre de 1993 y 19 de Diciembre de 2003, entre otros), que "la anulación de los actos administrativos por los que se aprueba el planeamiento urbanístico del que trae causa la expropiación deja sin efecto ni valor alguno las declaraciones de utilidad pública y necesidad de ocupación desapareciendo la causa expropiandi y acarreando todo ello la nulidad del procedimiento expropiatorio, incluido la determinación del justiprecio".

\section{d) En las Licencias}

29 Véase NIETO GARRIDO, E., "Emplazamiento personal a los afectados por la modificación puntual del Planeamiento Urbanístico en el contencioso-administrativo". RDU. $\mathrm{N}^{\circ}$ 287. Enero-Febrero 2014.

$30 \quad$ PLAZA GONZÁLEZ, M., "La nulidad de los instrumentos de Planeamiento General y la Preservación de los actos firmes dictados a su amparo", RDU. N $\mathrm{N}^{\circ}$ 312. Madrid - Marzo 2017. 
No ha sido exactamente igual la jurisprudencia, recaída sobre los puros actos de aplicación del planeamiento, como son las licencias, que la recaída sobre el planeamiento ${ }^{31}$.

Como ya señalaba el TS en Sentencia de 25 de marzo de 1991 "la nulidad de un Plan de Ordenación no provoca siempre la de las licencias otorgadas a su amparo" sino que quedan "subsistiendo en principio las que sean firmes por aplicación de lo dispuesto en la Ley de Procedimiento Administrativo, dado el carácter normativo de los Planes y la condición de aplicación de ellos de las licencias urbanísticas". Otra cuestión es la posición de las licencias no firmes, que quedan "solo ante el resto de la normativa urbanística vigente, que podrá decidir si las mismas son nulas de pleno derecho, anulables o incluso válidas".

¿Y qué ocurre por tanto con las licencias declaradas ilegales por nulidad del Planeamiento urbanístico? Como señala la Sentencia del TS de 27 de octubre de 2015, recurso 313/2014: "Cuando media una sentencia anulatoria de una licencia por disconformidad con el planeamiento la nueva ordenación no deja sin efecto aquella sino que acaso pudiera constituir un supuesto de imposibilidad legal de su ejecución." De acuerdo con el art. 5 del Reglamento de Disciplina Urbanística de Andalucía cuando la ejecución de la Sentencia sea imposible legal o materialmente, se llevará a efecto su cumplimiento por equivalencia mediante la indemnización correspondiente. El apartado 2 del art. 53, señala que en ese caso quedarán los actos de uso del suelo y en particular las obras, instalaciones y construcciones y edificaciones, en situación de asimilación a la de fuera de ordenación.

\section{El desequilibrio entre la obligación legal y el incumplimiento de la obligación interadministrativa de hacer efectivo el derecho a la vivienda como freno a la ejecución de la demolición de las edificaciones ilegales que constituyan el domicilio habitual familiar}

A) Derecho a la vivienda de los ciudadanos y deber interadministrativo

Entre los derechos de los ciudadanos, enumerados en el art. 5 TRLSRU, está el derecho a disfrutar de una vivienda digna, adecuada y accesible. A su vez el art. 34 del TRLSRU establece la obligación de los poderes públicos de adoptar las medidas necesarias para que los derechos y deberes de los ciudadanos sean reales y efectivos, subordinando y vinculando el uso residencial al derecho a disfrutar de una vivienda digna y adecuada en los términos que disponga la legislación en la materia.

31 Véase ESCRIBANO TESTAUT, P., "Las causas y los efectos directos y colaterales de la declaración de nulidad del PGOU de Ourense. Practica Urbanística. No 121 Marzo-Abril 2013. Editorial La Ley 
Como señala Vaquer Caballería ${ }^{32}$, aunque son muchos los usos a que se puede dedicar el suelo (forestal, agrícola, ganadero, industrial, etc.), la CE solo vincula de forma expresa la regulación de su utilización con uno de ellos, con el de la vivienda. Pero conviene advertir que "la vivienda a que se refiere el artículo 47 de la Constitución no es la vivienda como cosa sino la vivienda como hábitat". El bien que protege la Constitución no es la vivienda como un valor de inversión sino como vivienda habitual. No es que tengan que ser incompatibles ambas cosas, pero el objetivo preferente y primordial se centra en la vivienda como domicilio habitual. En el ámbito europeo, el art. 7 de la Carta de los Derechos Fundamentales de la Unión Europea establece que "toda persona tiene derecho al respeto de su vida privada y familiar, de su domicilio y de sus comunicaciones". Y el art. 47 de la Carta dispone que toda persona cuyos derechos y libertades garantizadas por el Derecho de la Unión hayan sido violados tiene derecho a la tutela judicial efectiva. La STJUE, de 10 de septiembre de 2014, asunto C-34/13, señala en su apartado 64 que el Tribunal Europeo de Derechos Humanos ha estimado que "la pérdida de una vivienda es una de las más graves lesiones del derecho al respeto del domicilio y que toda persona que corra el riesgo de ser víctima de ella debe en principio poder obtener el examen de la proporcionalidad de dicha medida.” (SS TEDH, McCann C. Reino Unido, demanda no 19009/04, apartado 50, y Rousk c. Suecía, demanda no 27183/04, apartado 137). Y también en su apartado 65, declara que en el Derecho de la Unión, "el derecho a la vivienda es un derecho fundamental garantizado por el art. 7 de la Carta".

La Constitución Española ha establecido en su artículo 47 el mandato a todos los poderes públicos de "promover las condiciones necesarias y establecer las normas pertinentes para hacer efectivo" el derecho a una vivienda digna y adecuada, en especial, "regulando la utilización del suelo de acuerdo con el interés general para impedir la especulación". No obstante, como dice Villalibre Fernández "33 "El derecho a una vivienda digna tiene unos límites en su exigibilidad establecidos por el artículo 53.3 CE, además de los límites económicos vinculados a la capacidad económica del Estado. Así, en cuanto a su justiciabilidad, solo puede ser alegado ante la jurisdicción ordinaria según lo que dispongan las leyes que lo desarrollen y, a día de hoy, no hay ninguna ley, ni estatal ni autonómica, que reconozca el derecho a toda persona para interponer un recurso ante la jurisdicción contencioso-administrativa exigiendo el derecho a una vivienda y, menos aún si cabe, digna y adecuada."

Con carácter general, las Administraciones públicas son titulares de Patrimonios de terrenos. En el ámbito de la Administración General del Estado, la Ley

32 VAQUER CABALLERÍA, M., "Estudio preliminar" del libro Comentarios a la ley de Suelo de PAREJO ALFONSO, L. y ROGER FERNÁNDEZ, R., IUSTEL 2007.

33 VILLALIBRE FERNÁNDEZ, V. "El derecho a una vivienda adecuada. Un derecho del siglo XXI". Estudios de Progreso. Fundación Alternatives 2011. 
33/2003, de 3 de noviembre, del Patrimonio de las Administraciones Públicas, en su art. 108 establece que las rentas, frutos o percepciones de cualquier clase o naturaleza producidos por los bienes patrimoniales de la Administración General del Estado se ingresarán en el Tesoro Público con aplicación a los pertinentes conceptos del presupuesto de ingresos, haciéndose efectivos con sujeción a las normas y procedimientos del derecho privado. Igualmente, en el apartado 2 del anterior artículo se establece que si la explotación conllevase la entrega de otros bienes, derechos o servicios, éstos se integrarán en el patrimonio de la Administración General del Estado o en un organismo público con el carácter de patrimonial, pero sin que se recoja afectación alguna. Así pues, los bienes del Patrimonio del Estado no son "finalistas" ni "cerrados", sino que se pueden "trasvasar" a través del Tesoro. Existen ejemplos concretos de gestión de Patrimonios Públicos de Suelo de Organismos dependientes de la Administración General del Estado o de otras Administraciones públicas que han actuado sin vinculación con los fines del art. 47 de la Constitución y han venido interviniendo en el mercado del suelo como un promotor inmobiliario más, tratando de obtener el mayor beneficio de la enajenación de su patrimonio, excusándose en la finalidad de reinvertir los ingresos en la mejora del servicio público de que se $\operatorname{trate}^{34}$.

Por otra parte, aunque el art. 183 de la LPAP prescribe que las Administraciones públicas ajustarán sus relaciones recíprocas en materia patrimonial al principio de lealtad, a través del art. 191.5 de la LPAP se le ha impuesto a los Ayuntamientos de manera imperativa y contraria a la autonomía municipal la obligación de custodiar y mantener los bienes desafectados a los que no se les haya dado una nueva calificación urbanística, una vez transcurridos dos años desde dicha desafectación.

El mandato del art. 47 de la Constitución, durante mucho tiempo, no ha contado demasiado para la Administración del Estado. Por ello, aunque de manera insuficiente aún, es digno de destacar la relativa vinculación al destino de VPO que contiene la Disposición Adicional Cuarta del TRLSRU que regula la Gestión de Suelos del patrimonio del Estado. Esta Disposición establece que es de aplicación a los bienes inmuebles que constituyen el patrimonio del Estado lo dispuesto en el TRLSRU sobre el control registral previsto en su art. 52 cuando se destine a la construcción de viviendas sujetas a algún régimen de protección pública. Pero solo en el caso que se refieran a enajenaciones de fincas destinadas a algún régimen de protección pública.

34 La Ley 28/1984, de 31 de julio, creaba la Gerencia de Infraestructura de la Defensa como Organismo Autónomo adscrito al Ministerio de Defensa destinada a realizar las actuaciones inmobiliarias y urbanísticas derivadas de la reordenación espacial de las fuerzas armadas con una vigencia temporal limitada. El Real Decreto de 6 de octubre de 2.000 aprueba el Estatuto de la Gerencia de Infraestructura y Equipamiento de la Defensa al que le confiere carácter indefinido y que tiene entre otras funciones la enajenación a título oneroso de bienes muebles o inmuebles, sin afectación alguna, siempre que sean declarados innecesarios y disponibles por el Ministerio de Defensa. 
Como no existe ninguna disposición que obligue al Estado a dedicar un porcentaje de sus inmuebles a la construcción de VPO, habrá que entender que el primer apartado de esta disposición se refiere a los bienes inmuebles que obtenga por la gestión urbanística y que están afectados a la construcción de VPO como consecuencia de la aplicación de la reserva mínima del $30 \%$ previsto en el art. 20 del TRLSRU ${ }^{35}$.

B. La protección judicial del derecho a la vivienda

El artículo 47 de la CE reservaba el derecho a la vivienda solamente para los españoles. El artículo 13 de la CE y la STC 107/1984 se lo concede a los extranjeros, a los que se lo otorguen las leyes y los Tratados. La Ley Orgánica 4/2000, de 11 de enero, sobre derechos y libertades de los extranjeros en España y su integración social, en su art. 13 reconoce el derecho de la vivienda a los extranjeros residentes que tengan "derecho a acceder al sistema público de ayudas en materia de vivienda en los términos que establezcan las leyes y las Administraciones competentes. En todo caso, los extranjeros residentes de larga duración tienen derecho a dichas ayudas en las mismas condiciones que los españoles".

En diversos países europeos se han llevado a cabo legislaciones que reconocen derechos de acceso a un alojamiento a personas que se encuentran sin un hogar. Destaca en primer lugar la legislación inglesa y del País de Gales, la Housing Act de 1996, de acuerdo con la cual los municipios tienen la obligación jurídica de alojar a ciertas clases de personas sin hogar. Los municipios tienen obligación de proporcionar alojamiento, inmediatamente que lo solicitasen, a toda persona sin hogar perteneciente a la categoría legal de personas "con necesidades prioritarias" (entre otras, mujeres embarazadas o personas con menores a su cargo). Tal alojamiento puede ser temporal, hasta que se encuentre una vivienda más adecuada, pública o privada. La legislación escocesa ha ido progresivamente reforzando la situación jurídica de las personas sin hogar, a partir de 2001, mediante la Hosing Scotland Act de ese año y en la Homelessness Scotland Act de 2003, se introduce un derecho de alojamiento de toda persona sin hogar, aunque no pertenezca a las categorías legales de "necesidades prioritarias" o, incluso, su situación resulte de su comportamiento. Los municipios deben tener una estrategia para los sin hogar por exigencia legal. En Francia, se aprobó la Ley de 5 de marzo de 2007, relativa al derecho al alojamiento oponible y a diversas medidas a favor de la cohesión social (Loi Instituant un droit au Logement Opposable, o DALO), que preveía el derecho a la solicitud de un alojamiento al sector público (para toda persona residente en Francia de modo regular y estable).

35 Vid del Autor "Comentario a la disposición adicional cuarta. Gestión de suelos del patrimonio del Estado", del libro Estudio del Articulado del Texto Refundido de la Ley de Suelo Estatal (RD Legislativo 2/2008, de 25 de junio, dirigido por GUTIERREZ GOLOMINA, V. y CABRAL GONZÁLEZ-SICILIA, A., Thomson Aranzadi 2009. 
La falta de cumplimiento de las obligaciones legales por la Administración permite la defensa del derecho legal ante los tribunales de justicia.

En España además de la Constitución, el derecho a la vivienda se recoge en los distintos Estatutos Autonómicos, así el Estatuto de Autonomía para Andalucía desarrolla esta regulación constitucional, incluyendo el derecho de vivienda entre los derechos sociales, deberes y políticas públicas y extendiendo este derecho a todas las personas con vecindad administrativa en Andalucía. El art. 25 del Estatuto de Autonomía de Andalucía (EAA) recoge el deber de los poderes públicos de realizar la promoción pública de la vivienda, para favorecer el ejercicio constitucional a una vivienda digna y adecuada. El art 56.1 del EAA establece que le corresponde a la Comunidad Autónoma la competencia exclusiva en materia de vivienda.

Se entiende por vivienda digna la que esté libre de inmisiones contaminantes, especialmente las referidas al ruido y a la que esté incardinada en un medio ambiente adecuado. Y además, en relación con la contaminación acústica, se ha ido produciendo una jurisprudencia que responsabiliza a la Administración por no tomar medidas efectivas que impidan la contaminación acústica. Esta jurisprudencia ha tenido como punto de partida la Sentencia del Tribunal Europeo de Derechos Humanos de 9 de diciembre de 1994, caso López Ostra contra España, a la que han seguido otras como las de 19 de febrero de 1998, caso Guerra contra Italia y la de 2 de octubre de 2001 contra el Reino Unido referida al aeropuerto de Heathrow. En estas sentencias se advierte que en determinados casos de especial gravedad ciertos daños ambientales, aunque no pongan en peligro la salud de las personas, pueden atentar contra su derecho a que se respete su vida privada y familiar, privándola del disfrute de su domicilio. Igualmente establecen que la exposición continuada a unos niveles intensos de ruido pone en grave peligro la salud de las personas, y que esta situación podrá implicar una vulneración del derecho a la integridad física y moral (art. 15 CE). También suponen una infracción de los derechos fundamentales a la intimidad personal y familiar (art. 18.1 GE) y a la inviolabilidad del domicilio (18.2 CE). Esta doctrina ha sido recogida igualmente por el TC (por todas, la STC 35/1995, de 6 de Febrero, FJ 3). El TS igualmente ha acogido esta doctrina y así, por ejemplo, en Sentencia de 29 de Mayo de 2003 condena al Ayuntamiento de Sevilla a indemnizar a un particular como consecuencia de la vulneración de su derecho fundamental a la inviolabilidad del domicilio, por no haber cerrado una discoteca que excedía del ruido permitido.

Los TSJ también han dictado una serie de sentencias en el mismo sentido anterior. Así, el TSJ de Andalucía (sede de Sevilla) por Sentencia de 29 de octubre de 2.001 estimó el recurso interpuesto por una Asociación de vecinos, demandando al Ayuntamiento de Sevilla para que tomara medidas contra "la movida". Igualmente, 
en una sentencia del TSJ de Andalucía (sede de Málaga), de 16 de Junio de 2003, de la que fue ponente Bernaldo de Quirós, se condenaba al Ayuntamiento de Vélez-Málaga a hacer cumplir la normativa autonómica sobre control de ruido y el control de la efectiva insonorización de los locales, así como indemnizar a los propietarios por los daños soportados.

Para que una vivienda sea digna y adecuada, además de estar libre de inmisiones contaminantes, debe ser accesible y con arreglo al principio de diseño para todas las personas. En efecto, como han puesto de relieve Ponce Solé y Fernández Evangelista $^{36}$ el derecho a la vivienda "no es solo el derecho al goce de un espacio habitable, o una morada, sino también el derecho a un medio urbano digno y adecuado en el que se inserta tal vivienda".

Algunas CCAA para contribuir al cumplimiento material de derecho a la vivienda, han incluido dentro de los bienes integrantes, los de dominio público, especialmente los dotacionales. Así, el art. 179 de la LSM de la CA de Madrid permite constituir derecho de superficie en los terrenos de su propiedad o integrantes del PMS con destino a vivienda sujeta a algún régimen de protección público o de integración social. ${ }^{37} \mathrm{El}$ art. 34.3 del Decreto Legislativo catalán 1/2010, de 3 de agosto, por el que se aprueba el Texto Refundido de la Ley de Urbanismo, establece la posibilidad de que el planeamiento urbanístico prevea como sistemas urbanísticos reservas de terrenos para viviendas dotacionales públicas dirigidas a satisfacer las necesidades temporales de colectivos de personas con necesidades de asistencia o de emancipación. El art. 55.6 de la Ley 1/2017, de 26 de Julio, de Navarra, por el que se aprueba el Texto Refundido de la Ley Foral de Ordenación del Territorio y Urbanismo, se refiere a la reserva obligatoria de terrenos para viviendas de titularidad pública, con carácter de dotación supramunicipal. El art. 81 de la Ley vasca 2/2006, de 30 de junio, de suelo y urbanismo, va aún más lejos y crea una obligación para municipios de 20.000 o más habitantes, que deberán calificar en sus planes suelo con destino a alojamientos dotacionales siempre por encima de un estándar fijado en la propia ley. En Andalucía la modificación del art. 10.1 A b) de la LOUA por la Ley 2/2012 ha incorporado la posibilidad de alojamientos transitorios en suelo de equipamiento público, cuya edificabilidad no computa dentro de la reserva de vivienda protegida.

36 PONGE SOLÉ, J. Y FERNÁNDEZ EVANGELISTA, G., "Derecho urbanístico, derecho a la vivienda y personas sin hogar. Nuevos desarrollos y perspectivas en España a la vista de las novedades europeas en la materia", $R D U . \mathrm{N}^{\circ} 256$.

37 Según el art. 174.1.d) Ley 9/2001, del Suelo de Madrid, los derechos sobre dotaciones supramunicipales obtenidas por cesión con destino a dotaciones para redes locales y supramunicipales, forman parte PMS. 
Domínguez Vila ${ }^{38}$, pone de relieve que las Administraciones Locales deben modificar el papel a desempeñar en la política de vivienda, donde como consecuencia de la situación económica, si bien no pueden suplir a las entidades de crédito y financiera, si pueden seguir ostentando un papel importante, en la estimulación de la construcción de viviendas protegidas. Lo que es indudable, es que los Ayuntamientos disponen de una serie de instrumentos, que pueden servir, mediante una utilización adecuada, para ayudar a facilitar de manera efectiva el derecho de la vivienda.

Lo cierto es que a pesar de todo el reconocimiento legal de la obligación interadministrativa y del derecho de los ciudadanos, la vivienda sigue siendo en España un problema sin resolver satisfactoriamente. Ello está incidiendo en una cierta ralentización tanto administrativa como jurisprudencial en las demoliciones de edificaciones ilegales que constituyen domicilio residencial, porque el Tribunal Supremo viene considerando, de manera reiterada, que "la demolición de un edificio o parte del mismo destinado a la morada familiar de su propietario, constituye una muy importante destrucción de riqueza material, implicando además una fuerte incidencia negativa en la convivencia normal de la familia y en las raíces psicológicas de las personas afectadas, que la destrucción de la propia vivienda lleva consigo, siempre de difícil reparación, independientemente de la mera entidad económica" (STS. de 7 de Marzo de 2001, REC 182/1999).

El incumplimiento por las Administraciones Públicas del deber de procurar la vivienda, ha originado en muchos casos, la suspensión de las órdenes de demolición en vía judicial de viviendas en general y especialmente las que constituyen vivienda habitual. En base al art. 130 LJCA que señala: "1. Previa valoración circunstanciada de todos los intereses en conflicto, la medida cautelar podrá acordarse únicamente cuando la ejecución del acto o la aplicación de la disposición pudieran hacer perder su finalidad legítima al recurso. 2. La medida cautelar podrá denegarse cuando de ésta pudiera seguirse perturbación grave de los intereses generales o de tercero que el Juez o Tribunal ponderará en forma circunstanciada".

Existe una constante jurisprudencia del Tribunal Supremo que entiende que en el caso de demolición de una vivienda, si no se adopta la medida cautelar de suspensión solicitada, la ejecución parcial o total de la vivienda, conllevaría perjuicios económicos y daños personales o morales, por la privación parcial o total de la vivienda de difícil reparación, incluso de imposibilidad material, en otros casos.

En efecto como señala la STS de 30 de Septiembre de 1996, Recurso de casación 6038/1993, existe una reiterada doctrina del TS, “de que toda orden de de-

38 DOMÍngUEZ VILA, A., "El Derecho Constitucional a la Vivienda Teoría y Práctica". $R D U$. $\mathrm{N}^{\circ} 271$ y 272. 2012. 
molición, en general, y específicamente, la atinente al domicilio familiar habitual, por su propia naturaleza, si se ejecuta prematuramente antes de la culminación del proceso pendiente en el que ha de decidirse acerca de su procedencia y legalidad, puede dar lugar, en el caso de quedar revocada posteriormente, a perjuicios de muy difícil reparación".

Esto ha originado una consolidada doctrina del Tribunal Supremo, vinculada al principio de proporcionalidad, que trata de evitar derribos que procederían por una estricta aplicación de las normas urbanísticas, pero que pugnaría con los principios de justicia material recomendando que la "drástica solución de la demolición, ya por ser extrema, impone la necesidad de ser aplicada con mesura y restrictivamente, a fin de evitar que con ella se origine un mal o resultado más grave que el producido por la discordancia entre lo autorizado y lo que se realiza, por lo que a aquella ha de llegarse solo excepcionalmente, en casos verdaderamente límites". Debe existir una "congruencia entre su fundamentación y los fines que la justifican." Por lo que "resulta procedente estimar la pretensión de la sentencia que no tuvo en cuenta tan reiterada aplicación del principio de proporcionalidad"39 (STS de 28 de Enero de 1987).

"El principio de proporcionalidad conlleva la necesidad de estar siempre al principio de no demolición.” En efecto, como señala la STS de 21 de enero de 1994 (Ponente Delgado Barrio, Francisco Javier) "la demolición da lugar a una destrucción de riqueza que puede resultar injustificada en caso de estimación del recurso contencioso administrativo y que, por tanto, exigencia inmediata del interés público ha de evitarse en tanto no exista sentencia firme" puesto que como dice la STS de 30 de Julio de 1996, Recurso de Casación 6022/1993, no debe considerarse como acto trámite el que conlleve la demolición de un edificio, "ya que la orden de demolición de un edificio, desde luego supone la coronación de la actividad administrativa". La STS, de 7 de marzo de 2001, Rec. 182/1999, reitera la anterior jurisprudencia acerca de la demolición del domicilio familiar habitual. Esta jurisprudencia del Alto Tribunal aún sigue impregnando la de los Tribunales Superiores de Justicia. Así la Sentencia del Tribunal Superior de Justicia de Madrid, de 16 de abril de 2014, dice que en los supuestos de demolición, debe ponderarse el interés público representado por la ejecución del acto administrativo y el particular del recurrente, que se centra en la conservación de lo construido; y por ello reconoce que "toda orden de demolición, por su propia naturaleza, implica destrucción de riqueza material, por lo que, si se ejecuta antes de la culminación del proceso pendiente en el que ha de decidirse acerca de su procedencia y legalidad, puede dar lugar, en el caso de que quede revo-

39 Véanse las Ss. TS de 2 de Octubre de 1972, 22 de Diciembre de 1978, 15 de Mayo de 1980, 19 de Septiembre de 1981, 25 de Mayo de 1982, 9 de Junio de 1982, 27 de Junio de 1983, 2 de Noviembre de 1983, 28 de Abril de 1984 y 9 de Abril de 1985. 
cada posteriormente, a perjuicios de muy difícil reparación", todo ello, de acuerdo con una reiterada jurisprudencia, de la que es exponente, entre otros, el Auto del Tribunal Supremo, de 30 de septiembre de 1996. En otra Sentencia del Tribunal Superior de Justicia de Madrid, del 17 de julio de 2017, Recurso de apelación 111/2017, se mantiene la anterior jurisprudencia, que se considera doctrina reiterada, pero dejando claro que "la demolición de una chabola no puede considerarse como un acto de destrucción de riqueza, el mantenimiento de la infravivienda dificulta la ejecución del planeamiento por lo que en ese caso el acto administrativo no puede ser suspendido." Se señala además que "el derribo está justificado por razones de salubridad, a más que no constituye el domicilio habitual del recurrente, que conforme a aquella vieja doctrina era condición sine qua non para que pudiera acordarse la suspensión de la demolición".

\section{Las luces y sombras de la regulación penal, administrativa y de la jurisdicción contencioso administrativa acerca de las medidas de protección de la legalidad sobre las edificaciones ilegales}

A. La obligatoriedad de la protección de la legalidad y de la reposición de la realidad física alterada

Como hemos dicho, las licencias ilegales otorgadas en base a un PGOU anuladas que sean firmes, quedarán subsistentes. En resto de los casos habría que distinguir las siguientes situaciones:

\section{a) Sin procedimiento judicial: Sólo administrativo}

Habría que diferenciar si existe o no una orden de demolición acordada. En el caso que no exista la orden de demolición acordada, y no hayan caducado las medidas de protección de la legalidad, es inexcusable el ejercicio de la potestad de protección de la legalidad, salvo que exista imposibilidad legal o material de su ejecución. Si se hubiera producido la caducidad de las medidas de protección de la legalidad, sería posible, según proceda, la aplicación del régimen de fuera de ordenación o el de asimilada al de fuera de ordenación, situaciones semiconsolidadas y situación legal de consolidación. (Art.3 1.B a) y b) del Decreto 2/2012, de 10 de Enero de Andalucía, art. 193 Ley Valenciana 5/2014, de Ordenación del Territorio, Urbanismo y Paisaje y art. 44 bis 1.a) del Texto Refundido de las Leyes de Ordenación del Territorio y de Espacios Naturales de Canarias DL 1/2000, de 8 de mayo, (actual art. 159.1.a de la ley 4/2017 de 13 de julio, del Suelo y de los Espacios Naturales Protegidos de Canarias) respectivamente.

En segundo lugar, cuando exista una orden de demolición acordada por órgano administrativo pero no judicial, si no ha prescrito esta orden de demolición, debe 
ejecutarse inexcusablemente ${ }^{40}$, salvo que exista una imposibilidad legal o material y así se acredite en un expediente individualizado, por el órgano administrativo competente, "sin perjuicio de la potestad jurisdiccional de hacer ejecutar lo juzgado, en los casos que haya recaído resolución judicial firme. Art.51.1 RDUA).

La legislación urbanística no ha regulado la prescripción de esta orden de demolición y se aplicaba, mayoritariamente el plazo general de prescripción de 15 años del art.1964 CG a contar desde la firmeza (Sentencias Tribunal Supremo 11 julio 1985, 5 de junio 1987, 17 de febrero 2000. De manera minoritaria el Tribunal Superior de Justicia de Madrid señalaba aplicable el plazo quinquenal previsto para la demanda ejecutiva del art. 518 LEC. La STS 29, de diciembre 2.010, desestimó la anterior doctrina jurisprudencial del TSJM. Actualmente, la DT Quinta de la ley 42/2015 ha modificado el plazo de prescripción del Cc, reduciéndolo a 5 años. Y para el régimen transitorio se remite al art. 1939 Cc.

\section{b) Con procedimiento judicial firme}

Deberá, como hemos señalado, cumplirse la ejecución de la sentencia en sus propios términos, salvo en los que así se determine, en el caso de imposibilidad legal o material, por el propio poder judicial. O bien haya prescrito el plazo de ejecución de la orden de demolición, referida en el apartado anterior. Ha habido varios intentos en la legislación autonómica para alterar en alguna medida las condiciones a que debe someterse la ejecución de sentencias que lleven aparejado el derribo de edificaciones ilegales, afectando por tanto a la competencia judicial. Así el art.65 bis.1 de la Ley cántabra 2/2001, añadido por la Ley 4/2013 de 20 de junio, estableció la posibilidad que el órgano municipal competente autorizara provisionalmente su mantenimiento en la situación existente y se produjera la suspensión provisional de las ordenes de demolición administrativas o judiciales, previa comprobación que resultaban conformes con el nuevo planeamiento municipal en tramitación. La STC 254/2015 declaró nulo e inconstitucional el inciso "judicial", dejando subsistente exclusivamente las "administrativas". A su vez la Disposición adicional sexta de la Ley 8/2012, de 29 de junio, de Vivienda de Galicia reconoció, a los titulares de las viviendas construidas al amparo de un título anulado, el derecho a residir en el inmueble mientras no se determinase por la Administración competente, a través del correspondiente procedimiento de responsabilidad patrimonial, el alcance de la indemnización que pudiera corresponderles, al haber establecido que el acto administrativo o sentencia firme que determinara la anulación del título e implicara la reposición de la legalidad urbanística y la demolición de lo construido, llevaría consigo, como efecto legal

40 Véase GUTIERREZ COLOMINA, V. "La protección de la legalidad en el régimen urbanístico de Andalucía”. Practica Urbanística. No112. El Consultor, Febrero 2012. 
necesario la apertura de oficio del procedimiento de responsabilidad patrimonial. La STC 82/2014 de 28 de mayo declaró nulo el inciso "o Sentencia” del apartado 2 de la DA sexta de la ley 8/2012, por lo que a partir de ésta, la DA sexta sólo regulará el procedimiento a seguir cuando la anulación del título, se produzca mediante acto administrativo firme y no por sentencia, puesto que aquel no afecta al ejercicio de la potestad jurisdiccional, ni a la competencia reservada al Estado en materia de legislación procesal (arts. 117.3 y 149.1.6 CE).

B. La incidencia de las modificaciones de la legislación penal y de la jurisdicción contencioso administrativa sobre la ejecución de las sentencias sobre edificaciones ilegales

\section{a) La modificación del art. 319 del Código Penal}

En el ámbito de la legislación estatal se han producido dos modificaciones que afectan decididamente a esta cuestión y que es indudable que acrecientan los requisitos, y por ende las dificultades para la ejecución de las sentencias urbanísticas sobre la demolición de edificaciones ilegales ${ }^{41}$. La primera ha sido la del Código Penal, llevada a cabo, adicionando por el número ciento setenta y uno del artículo único de la Ley Orgánica 1/2015, de 30 de marzo por la que se modifica la LO 10/1995, del Código Penal, un apartado 3 al art.319 que dice:

"En cualquier caso, los jueces o tribunales, motivadamente, podrán ordenar, a cargo del autor del hecho, la demolición de la obra y la reposición a su estado originario de la realidad física alterada, sin perjuicio de las indemnizaciones debidas a terceros de buena fe, y valorando las circunstancias, y oída la Administración competente, condicionarán temporalmente la demolición a la constitución de garantías que aseguren el pago de aquéllas. En todo caso se dispondrá el decomiso de las ganancias provenientes del delito cualesquiera que sean las transformaciones que hubieren podido experimentar".

En relación con esta innovación del Código Penal conviene destacar que la suspensión temporal de la demolición para la constitución de garantías para hacer frente a las indemnizaciones a terceros de buena fe, encomendada por el poder legislativo al judicial, tiene carácter facultativo y no imperativo. Y además, el Juez deberá hacerlo valorando las circunstancias y oída la Administración competente. Al no ser de aplicación automática, ni de carácter imperativo, no parece que pueda tener riesgo de inconstitucionalidad.

41 ALONSO IBÁÑEZ, M. R., "La imposibilidad de ejecución de sentencias de demolición de edificaciones. Medidas Legales". Obra colectiva Por el Derecho y la Libertad. Libro Homenaje al Prof. Fuan Alfonso Santamaría Pastor. Iustel, Madrid 2014. 
Conviene resaltar, como dice Fernández Aparicio ${ }^{42}$, que desde un punto de vista legal no es "plenamente coincidente la demolición en sede administrativa con la demolición en sede penal. Hay divergencias significativas en cuanto a la naturaleza y plazo de prescripción".

La STS, Sala $3^{\text {a }}$, de 30 de junio de 2000, ponía de relieve que la demolición "no constituye una sanción propiamente dicha sino el mecanismo adecuado para restaurar la legalidad vulnerada. La demolición es compatible y distinta de la imposición de sanciones a los responsables." Fernández Aparicio, en la obra citada anteriormente, señala que el legislador debía de haber incluido la demolición en alguno de los siguientes apartados: "pena, responsabilidad civil o consecuencia accesoria del delito". En el ámbito de los delitos contra la Ordenación del Territorio se han producido una serie de Sentencias del Tribunal Supremo bastante relevantes, como las Ss. de 27 de noviembre de 2009, 21 de marzo de 2012, 21 de junio de 2012 y 22 de noviembre de 2012.

La sentencia del Alto Tribunal de 21 de junio de 2.012 dice que "La demolición de la obra o reposición a su estado originario a la realidad física alterada son medidas que poseen un carácter civil más que penal. Se trata de restaurar la legalidad, de volver a la situación jurídica y fáctica anterior a la consumación del medio. Según la doctrina mayoritaria se trata de una consecuencia jurídica del delito en cuanto pudieran englobarse sus efectos en el art. 110 CP. Implica la restauración del orden jurídico conculcado y en el ámbito de la política criminal es una medida disuasoria de llevar a cabo construcciones ilegales que atenten contra la legalidad urbanística: No se trata de una pena al no estar recogida en el catálogo de penas que contempla el CP". "La consideración de la demolición como consecuencia jurídica del delito permite dejar la misma sin efecto si, después de establecida en sentencia, se produce una modificación del planeamiento que la convierta en innecesaria, por lo que la posibilidad de una futura legalización no obsta a su ordenación en el ámbito penal".

En efecto es cierto, que el precepto que analizamos establece la demolición de forma no imperativa, pero ni el tenor literal del art. 319.3 anteriormente vigente, ni la redacción actual a la que nos estamos refiriendo, como reconoce la sentencia Penal 152/2016, Audiencia Provincial de Cáceres, de 10 de mayo, permiten afirmar que la demolición de lo construido sea la consecuencia obligada, necesaria e ineludible de la comisión de un ilícito de esta naturaleza. El "En cualquier caso..." con el que se inicia la redacción del artículo puesto en relación con la elección del verbo escogido en el predicado -"podrán"- sólo podemos interpretarlo en el sentido de que cuando el legislador menciona "en cualquier caso" se está refiriendo a que tanto los supuestos

42 FERNÁNDEZ APARICIO, J. M., "Regularizaciones administrativas y su incidencia en los delitos urbanísticos. La demolición”, RDU. No 284. Septiembre - Octubre 2013. 
a los que se refiere el núm. $1^{\circ}$ del precepto como los del núm. $2^{\circ}$, cabe la posibilidad de la demolición".

Así por regla general, como recoge la doctrina jurisprudencial del TS, la demolición deberá acordarse cuando conste patentemente que la construcción de la obra está completamente fuera de la ordenación y no sean legalizables o subsanables, en aquellos supuestos en que haya existido una voluntad de rebelde del sujeto activo del delito a las órdenes o requerimientos de la Administración y en todo caso, cuando al delito contra la ordenación del territorio se añada un delito de desobediencia a la autoridad administrativa o judicial.

Así pues, para demoler, en principio podría estimarse bastante y suficiente la comisión de un delito contra la ordenación del territorio unido a la persistencia o permanencia de la obra infractora para acordar la restauración del orden quebrantado, sin que quepan aquí referencias al principio de intervención mínima, que no es un principio de interpretación del derecho penal sino de política criminal y que se dirige fundamentalmente al legislador que es a quien incumbe mediante la fijación en los tipos y las penas, cuáles deben ser los límites de la intervención del derecho penal -ni tampoco al de proporcionalidad, pues siempre será proporcionado acordar la demolición cuando sea la única vía posible para restaurar el orden quebrantado.

La Sentencia 152/2016, de la Audiencia Provincial de Cáceres, en relación con los tres motivos que el juzgado de instancia había rechazado para la demolición de vivienda ilícitamente edificada, como eran el destino a vivienda habitual, el no estar levantada dicha edificación en espacio protegido o singular alguno, junto con su aparición al lado de otras construcciones en el mismo enclave, los ha desestimado interpretando lo siguiente:

En primer lugar, señala que dos de ellos aparecen expresamente rechazados en la jurisprudencia del TS citada, en la que se señala que la demolición resulta aplicable no solo a la modalidad cualificada por la naturaleza del suelo como viales, zonas verdes, bienes de dominio público o lugares que tengan legal o administrativamente reconocido su valor paisajístico, ecológico, artístico, histórico o cultural, o por los mismos motivos hayan sido considerados de especial protección a que se refiere el artículo 319.1 del Código Penal (RCL 1995, 3170 y RCL 1996, 777), como también a su modalidad básica del artículo 319.2 ("suelo no urbanizable"), y considera que no es argumento de suficiente peso que no pueda repararse todo el daño causado genéricamente en la zona por existir otras construcciones en ella, pues supondría una torticera interpretación de la normativa urbanística en vigor con la finalidad de alterar el régimen jurídico del suelo -suelo urbano donde no lo había- y posibilitar luego una consolidación de las edificaciones con una apariencia de legalidad y con afectación de terceros de buena fe, los posibles compradores. 
La otra razón sobre la que se sustenta la decisión impugnada es la de que la vivienda construida por el condenado no estaba destinada al ocio sino a su uso como vivienda habitual. Pero el destino de la edificación es una cuestión ajena al delito tipificado en el artículo 319 del Código Penal, para el que dicho destino sea ocio, sea desarrollar una actividad productiva o residencial, resulta algo intrascendente. El Tribunal Supremo, en su sentencia de 21 de junio de 2.012 (RJ 2012, 6963), que se transcribe en la de 24 de noviembre de 2.014 (RJ 2014, 6004), lo que hace es tomar en consideración ese destino como uno de los datos que pueden tenerse en cuenta a la hora de ponderar la "proporcionalidad de la medida en relación con el daño que [la demolición] causaría al infractor, en caso de implicarse sólo intereses económicos, o verse afectados derechos fundamentales, como el uso de la vivienda propia". Es cierto que la adopción de esta medida, precisamente "por no ser de automática y necesaria imposición", no debe afectar a derechos fundamentales, y uno de ellos es el que todos tienen a "a disfrutar de una vivienda digna y adecuada" ( artículo 47 de la Constitución (RCL 1978, 2836) ), pero no es menos cierto que los derechos fundamentales deben ejercitarse, siempre que ello sea posible, de forma que no se afecten otros derechos fundamentales que, por ser esenciales, constituyen bienes jurídicos penalmente protegidos.

No basta con que el uso de la edificación sea el de vivienda, pues el derecho a una vivienda digna no es absoluto y no autoriza, sin más, a edificar donde uno quiera. Para considerar desproporcionada la demolición por afectar al derecho a una vivienda digna es necesario algo más, de forma que la vivienda que se pretende demoler sea la única opción razonable para el condenado de gozar de una vivienda, es decir, por ejemplo, que no sea titular catastral de otra vivienda o que no disponga de recursos económicos para procurarse lícitamente una vivienda.

En definitiva, el Tribunal Supremo establece como regla general la demolición como el medio más eficaz y necesario para restaurar el orden jurídico perturbado. Las excepciones a esta regla general serían la extralimitación mínima y la posterior legalización.

En opinión de Fernández Aparicio ${ }^{43}$ los procesos de regularización no deben afectar a la demolición en ninguna de las fases del proceso y la inejecución total o parcial de la demolición como consecuencia de una modificación del planeamiento o por imposibilidad material de llevarlo a cabo, deben estar justificados.

Tienen bastante interés algunos acuerdos sobre unificación de criterios sobre la demolición de obras ilegales, como el llevado a cabo por la Audiencia Provincial

43 FERNÁNDEZ APARICIO, J.M., (2013). 
de Málaga ${ }^{44}$. En estos acuerdos destaca lo siguiente en relación con la demolición de sentencias firmes en delitos referentes a la ordenación del territorio:

- El incumplimiento deliberado por parte del condenado de la obligación de demoler lo construido, puede ser tenido en cuenta, junto con el resto de factores concurrentes, en el momento de resolver el otorgamiento o no de la suspensión de la ejecución de la pena impuesta. Pudiéndose además condicionar dicha suspensión a la ejecución de la demolición acordada en el plazo impuesto por el órgano que haya dictado la sentencia.

- Se establece el carácter excepcional de la suspensión de la demolición por la posible regularización de lo construido y siempre que se aporte documentación acreditativa que esta regularización resulta viable, no bastando la sola aportación de la solicitud dirigida al ayuntamiento competente.

\section{b) La incidencia de la reforma de la Ley de furisdicción Contencioso Administrativa}

\section{i. Modificación del Recurso de Casación}

A través de la DF tercera de la Ley Orgánica 7/2015, de 21 de julio, por la que se modificaba la Ley Orgánica 6/1985, de 1 de julio, del Poder Judicial, se acometió una importante reforma del recurso de casación que ha originado la supresión de los recursos de casación para la unificación de doctrina y en interés de Ley. Judith Gifreu $^{45}$ dice que en realidad, la Ley Orgánica 7/2015, ha transformado lo que hasta ahora era un simple recurso extraordinario de revisión en el instrumento por excelencia para asegurar la uniformidad en la aplicación judicial del Derecho, de ahí que se prescinda en el orden contencioso-administrativo de las modalidades de los recursos de casación en interés de Ley y para la unificación de doctrina, cuyos presupuestos quedan subsumidos en el nuevo recurso de casación. Como destacaba Pérez Alonso, ${ }^{46}$ este nuevo modelo de casación en la jurisdicción contencioso administrativa tiene como elemento clave, a efectos de la admisión, el "interés casacional", "recordando en gran manera el existente en el Tribunal de los Estados Unidos para la admisión de "writ of certiorari", que ha permitido al Tribunal Supremo de los Estados Unidos un control total sobre su trabajo, hasta tal punto que del total de

44 Acuerdos adoptados por la Junta de Magistrados Penales de dicha Audiencia, el 9 de noviembre de 2017, tomando conocimiento por la Presidencia de la Audiencia Provincial el 29 de enero de 2018.

45 GIFREU FONT, J., "Reflexiones críticas en torno al control jurisdiccional de la actividad urbanística de los entes locales". RDU. No 310, Madrid, diciembre 2016.

46 PÉREZ ALONSO, J., "El nuevo sistema de casación en el orden contencioso administrativo operado por la Ley Orgánica 7/2015, de 21 de julio, con la vista puesta en el certiorari estadounidense".

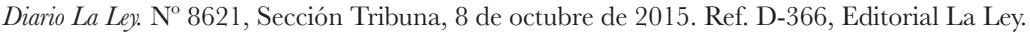


recursos presentados en los últimos años, se sitúa en uno por ciento los recursos que se suelen resolver, al eliminarse con carácter general las apelaciones y establecerse como única vía, en la práctica, el "writ of certionari” para acceder al Tribunal Supremo, limitado además a conocer supuestos en los que existen diversos criterios jurisprudenciales entre dos o más Tribunales de Apelación o donde se persiga para su resolución, en cuanto al fondo, un juicio de constitucionalidad de las leyes aplicables al caso enjuiciado.

A tal efecto en la nueva regulación del recurso de casación, el interés casacional, que es un concepto jurídico indeterminado, se exige en el fundamento exclusivo en que se basa su admisión.

De esta reforma es destacable lo siguiente:

- Se introduce un nuevo trámite según el cual la admisión o inadmisión del recurso será decidida por una Sección de la Sala de lo Contencioso Administrativo del Tribunal Supremo (art. 90.2 LRJCA).

- La distinción entre dos tipos de asuntos, en primer lugar, cuando se invoque una concreta infracción del Ordenamiento jurídico, bien de carácter procesal como sustantiva, o de la jurisprudencia, y la Sala considere que existe interés casacional objetivo para la formación de jurisprudencia. (art. 88.2 LRJCA), debiendo motivarlo expresamente en el auto de admisión y se refiera, entre otros, a los supuestos siguientes:

Cuando fije, ante cuestiones sustancialmente iguales, una interpretación de las normas de Derecho estatal o de la Unión Europea, siente una doctrina sobre estas normas gravemente dañosa para los intereses generales, afecte a un gran número de situaciones, resuelva un debate que haya versado sobre la validez constitucional de una norma con rango de ley, interprete y aplique aparentemente con error y como fundamento de la decisión una doctrina constitucional, aplique el Derecho de la Unión Europea en contradicción aparente con la jurisprudencia del Tribunal de Justicia y resuelva un proceso en que se impugnó, directa o indirectamente, una disposición de carácter general o un convenio celebrado entre Administraciones públicas, dictada en el procedimiento especial de protección de derechos fundamentales.

Y en segundo lugar, en los supuestos en que se presuma la existencia de interés casacional objetivo, entre otros las siguientes: cuando en la resolución impugnada se hayan aplicado normas que sustente la decisión sobre las que no exista jurisprudencia, o se aparte deliberadamente de la jurisprudencia existente, la sentencia recurrida declare nula una disposición de carácter general, salvo que carezca de trascendencia, o resuelva recursos contra actos o disposiciones de los organismos reguladores o 
de supervisión o agencias estatales cuyo enjuiciamiento corresponde a la Audiencia Nacional.

- En los párrafos segundo y tercero del apartado 3 del artículo 86 se establecen una serie de medidas organizativas referentes a los Tribunales Superiores de Justicia ${ }^{47}$.

- El Art. 86, abre la casación a las Sentencias dictadas en única instancia por los Juzgados de lo Contencioso Administrativo, pero solo en el caso de "sentencias que contengan doctrina que se reputa gravemente dañosa para los intereses generales y sean susceptibles de extensión de efectos".

Es indudable que esta reforma del recurso de casación va a incidir en el urbanismo de una manera considerable. De un lado bajo una perspectiva cuantitativa, por la inclusión de las sentencias dictadas por los Juzgados de lo Contencioso Administrativo que tienen una amplia competencia en el ámbito urbanístico. Y de otro lado porque existen una serie de temas urbanísticos de indudable trascendencia que previsiblemente, como señala Gifreu Font ${ }^{48}$, van a tener un interés objetivo casacional, como son los convenios interadministrativos y con particulares ${ }^{49}$ que se declaren nulos o cuando haya que aplicarse normativa de reciente aprobación de la que no exista jurisprudencia, así como las operaciones de rehabilitación, regeneración, renovación urbana y los problemas de desconsolidación del suelo urbano.

\section{ii. La reforma del art. 108.3 de la LJCA}

ii.1.- Incidencia en la ejecución de sentencias urbanísticas.-Junto a esta reforma del recurso de casación, la Ley 7/2015, de 21 de julio, por la que se modifica la Ley Orgánica del Poder Judicial, introdujo otra importante modificación por su incidencia en el ámbito urbanístico, como es la llevada a cabo en el art. 108 de la LRJCA, para adaptarse a la modificación del Código Penal, introduciendo en el apartado cuarto de la disposición final tercera, el apartado 3 del art. 108 en la $\mathrm{LJCA}^{50}$, que señala lo siguiente:

$47 \quad$ El Pleno del Tribunal Constitucional, por providencia de 19 de junio de 2018 (BOE 26-6-2018) ha acordado admitir a trámite la cuestión de inconstitucionalidad n ${ }^{\circ} 2860-2018$ planteada por el Tribunal Superior de Justicia de Castilla La Mancha, en relación con el art. 86.3 párrafos segundo y tercero de la LJCA, por posible vulneración de los arts. 9.3, 14 y 122.1 de la CE.

48 GIFREU FONT, J. (2016).

49 Se ha reforzado, en el ámbito local, la seguridad jurídica de estos Convenios, al exigirse informe preceptivo del Secretario del Ayuntamiento, mediante el Real Decreto 128/2018, de 16 de marzo, por el que se regula el régimen jurídico de los funcionarios de Administración Local con Habilitación Nacional.

50 Enmienda de Adición presentada por el Grupo Socialista, en la que señala que se formulaba en aras de fomentar la seguridad jurídica y el tráfico jurídico, para proteger el derecho de propiedad, y de 
"El Juez o Tribunal, en los casos en que, además de declarar contraria a la normativa la construcción de un inmueble, ordene motivadamente la demolición del mismo y la reposición a su estado originario de la realidad física alterada, exigirá, como condición previa a la demolición, y salvo que una situación de peligro inminente lo impidiera, la prestación de garantías suficientes para responder del pago de las indemnizaciones debidas a terceros de buena fe".

Esta regulación provoca alguna contradicción con algunos postulados de la doctrina del Tribunal Supremo, como el reiterado en la sentencia del TS de 9 de febrero de 2009, Recurso Casación 1745/2007, que había establecido que "la ejecución de la Sentencia obliga a la adopción de las medidas necesarias de demolición de las obras que resultan carecer de la licencia como consecuencia de la anulación acordada en dicha sentencia, siendo por completo inaceptable que la demolición así procedente según lo acordado por la Sala se haga depender de un nuevo expediente de protección de la legalidad urbanística", mientras que esta nueva regulación exige que además de declarar contraria a la normativa la construcción de un inmueble, se ordene motivadamente la demolición del mismo.

Por otra parte, el carácter imperativo para el juez de la exigencia de garantías suficiente para hacer frente al pago de las indemnizaciones debidas a terceros de buena fe, plantea una cierta incertidumbre en la interpretación del precepto y su contenido dejaba irresueltas, entre otras cuestiones, la cuantía de las garantías, el plazo de suspensión y el sujeto a quien le corresponde hacer frente a las garantías y cuya determinación, obviamente, complicará y alargará el procedimiento de ejecución. Al respecto como señalan Revuelta Pérez y Narbón Laínez" "el análisis del tratamiento de los terceros de buena fe en las jurisdicciones civil y penal, permite comprobar que, a diferencia de lo que ocurre en el orden contencioso administrativo en materia de urbanismo, se considera causa de imposibilidad legal." Y por ello concluyen que no existe razón convincente para que no se aplique el mismo criterio en la jurisdicción contencioso administrativa y que por ello debería reformularse el tratamiento de los terceros de buena fe, en el tratamiento de las sentencias, en particular, en las que anulan licencias. Esta modificación del art. 108.3 LJCA parece seguir esta corriente de protección al tercero de buena fe, aunque algunos opinan que no es asín ${ }^{52}$. El ATS 8042/2017, admitió a trámite

forma análoga al cambio introducido en el Código penal para proteger a terceros adquirentes de buena fe.

${ }_{51}$ REVUELTA PÉREZ, I. y NARBÓN LAÍNEZ. E., "Ejecución de Sentencias en materia urbanística, demolición y terceros adquirentes de buena fe. El caso de la anulación de licencias". Revista Crítica de Derecho Inmobiliario. $\mathrm{N}^{\circ} 720$.

${ }^{52}$ MEDIAVILLA CABO, J. V., "El artículo 108.3 de la ley Reguladora de la Jurisdicción Contencioso-Administrativa a la luz de la reciente jurisprudencia del Tribunal Supremo. Innecesaridad de indemnizar con carácter previo o simultaneo a la demolición". RDU. No 322. Junio 2018. Este autor opina que el 
el recurso de casación dictado en ejecución de sentencia, porque estima que debe esclarecerse la cuestión de si el concepto de tercero de buena fe debe entenderse que comprende a los titulares de otros derechos, distintos de propiedad que puedan surgir como consecuencia de la demolición y si corresponde al juez o tribunal promover la identificación y emplazamiento de los terceros de buena fe titulares de un eventual derecho de indemnización. En mi opinión la protección a los terceros de buena fe prevista en este artículo debería darle un plus a la salvaguarda del derecho a la vivienda como domicilio habitual familiar, bien al propietario o al que tenga otro tipo de derecho legal sobre dicho domicilio, como a un arrendatario. $\mathrm{Al}$ efecto señalan Alonso Mas y Revuelta Pérez" ${ }^{53}$ el margen de apreciación, "se estrecha considerablemente cuando lo que se halla en juego es el derecho a la vida privada y familiar".

Díaz Murias ${ }^{54}$ opinaba que para la aplicación de este precepto era preciso determinar e identificar a los posibles terceros de buena fe, determinar las cuantías de las indemnizaciones debidas y posteriormente garantizar la inclusión de las partidas correspondientes y la tramitación de los correspondientes expedientes de responsabilidad patrimonial. Entendiendo que para "la tramitación de tales expedientes, es preciso suspender la ejecución del Fallo, y simultáneamente tramitar conforme a la Ley los expedientes de responsabilidad patrimonial." Sin embargo no es congruente este planteamiento con lo dispuesto en la STG 82/2014 de 28 de mayo de 2014 que anuló parcialmente la Disposición adicional sexta de la ley 8/2012, de 29 de junio, de vivienda de Galicia, únicamente en lo referente a la fase de ejecución de sentencia, porque el precepto anulado se refiere a la "efectiva resolución y al pago de la indemnización acordada de suerte que la ejecución de la sentencia termina por escapar del control judicial, único competente para hacer ejecutar lo juzgado a tenor de lo dispuesto en el art. $117.3 \mathrm{CE}$ que resulta igualmente vulnerado".

\section{ii.2. La reciente jurisprudencia del TS sobre el art. 108.3}

Se han admitido por el TS una serie de recursos de casación justificándose el interés casacional por no existir jurisprudencia para determinar "si la exigencia de la prestación de garantías suficientes para responder del pago de las indemnizaciones debidas a terceros de buena fe, a la que hace referencia el artículo 108.3 de la Ley Ju-

art. 108.3, interpretando en el sentido que lo ha hecho el TS no conlleva ninguna mejora en el tercero de buena fe.

53 ALONSO MAS, $\mathrm{M}^{\mathrm{a}} \mathrm{J}$. y REVUELTA PÉREZ, I., Buena fe contra demolición urbanística. Thomson Reuters Aranzadi 2017.

54 DÍAZ MURIAS, R. "El recurso de casación y demoliciones urbanísticas". El Consultor de la Ayuntamientos. No 13, Sección Opinión/Comentarios de Jurisprudencia, Quincena del 15 al 29 de Julio. 2017, Ref.: 1737/2017. 
risdiccional como condición previa a la demolición de un inmueble ordenada por un Juez o Tribunal, precisa la tramitación de un procedimiento contradictorio y requiere que tales indemnizaciones hayan sido fijadas como debidas en un procedimiento de responsabilidad patrimonial o en un incidente de inejecución de sentencia con intervención de las partes implicadas, en el que habrá de determinarse la existencia de terceros de buena fe y su identidad, y durante cuya sustanciación no podría llevarse a efecto la demolición acordada por el Juez o Tribunal”. (Autos TS 5094/2017, 1596A/2017 y 8042/2017, entre otros).

Se ha resuelto en primer lugar el recurso planteado contra Auto de 11 de enero de 2016, de la Sala de lo Contencioso Administrativo del TSJ de Galicia, que inadmite a trámite el incidente de inejecución de Sentencia por imposibilidad legal. En el fundamento de Derecho Decimo y s.s. de la Sentencia del Tribunal Supremo, de 21 de septiembre de 2017, Recurso de casación 477/2016, de la que es ponente Cesar Tolosa Triviño, entra a analizar la incorporación del art. 108.3 al proceso de ejecución, y señala lo siguiente:

- La ley procesal no se aplica retroactivamente a procesos anteriores, sino a los actos procesales que se producen a partir de su entrada en vigor, aunque los hechos materiales y jurídicos que han dado origen al proceso sean anteriores. En definitiva, al tratarse de una norma procesal, incluida en legislación procesal y además sobre incidente procesal de ejecución, resulta de aplicación a todos los supuestos o incidentes en que se plantee el momento, alcance al modo de demolición de una construcción ilegal, al margen de cuando se haya iniciado el pleito o incidente de ejecución.

- Interpretar el nuevo artículo 108.3, considerando que constituye un supuesto de suspensión o inejecución de sentencia, obligaría a plantear serias dudas en el sentido que la suspensión automática de la ejecución de una sentencia, no resulta conforme ni compatible con el derecho a la tutela judicial efectiva, que se concreta en un derecho de contenido prestacional a que la sentencia sea llevada a su debido efecto y en sus propios términos.

- El legislador no ha modificado el art. 105.1 LJCA, cuya prohibición de suspender sigue vigente sin matiz alguno, sino que lo que ha hecho, ha sido incorporar dicha medida dentro del art. 108 LJCA, precepto que tanto desde una perspectiva temporal como sistemática permite afirmar que el legislador no ha pretendido dispensar a los propietarios y a la Administración de una medida genérica e indiscriminada de suspensión o paralización temporal de las ejecuciones de las Sentencias de demolición de inmuebles, sino de dotar al juez, una vez acreditada la necesidad, adecuación y proporcionalidad de la demolición, de determinados poderes en orden a que dicha demolición 
no haya de causar efectos irreparables en los terceros adquirentes de buena fe. El art. 108.3 se sitúa en un momento posterior del proceso de ejecución, en cuanto se incluye en un precepto que recoge los poderes del juez para que la ejecución se lleve a efecto, se convierte en una fase más de la ejecución, pero nunca en un impedimento, ni siquiera temporal para la ejecución de la sentencia. La norma no establece un obstáculo a la ejecución, sino añade un deber de hacer en la ejecución de estos fallos. Al deber de demoler, se une el de garantizar los perjuicios que puedan derivarse para los adquirentes de buena fe. En caso de no hacerlo, el juez debe ocuparse de que así sea, adoptando medidas de coerción y exigiendo responsabilidades de todo tipo, hasta que se haya constituido la garantía, voluntariamente o de forma forzosa. En ningún caso la Sentencia condiciona la ejecución a la resolución de expediente de responsabilidad alguna. Por ello, el supuesto contemplado en el art. 108.3, no se trata de imposibilidad ni material ni legal de ejecutar la sentencia.

En segundo lugar es destacable la STS 1900/2017 de 4 de diciembre, RC 832/2016, de la que es ponente Rafael Fernández Valverde, en un incidente de ejecución de la sentencia de "El Algarrobico", señala que entre las cuestiones que se pueden plantear vía incidental en base al art. 109, estarían en determinados supuestos los relacionados con la ejecución de sentencias, como los que se suscriben al amparo del art. 108.3 LJCA y que esta vía incidental del art. 109, posibilita que "el periodo probatorio sería viable en este incidente". Y que en lo referente a los terceros de buena fe no puede limitarse o blindarse al tercero registral del art. 34 del Reglamento Hipotecario.

Posteriormente se han dictado una serie de SsTS que han delimitado e interpretado sin género de dudas la doctrina jurisprudencial sobre el art. 108.3, como son las de 21 de marzo de 2018, Recursos de Casación 138/2017 y 141/2017 y de 25 de mayo de 2018, recurso 325/2016.

De las dos primeras conviene destacar, en primer lugar que ratifican la jurisprudencia anterior a la aprobación del art. 108.3 LJCA, en el sentido de que el derecho a la ejecución de las sentencias en sus propios términos forma parte del derecho fundamental a la tutela judicial efectiva. Y en segundo lugar que considera como la “interpretación más acertada del art. 108.3, que la exigencia de la prestación de garantías suficientes para responder del pago de las indemnizaciones debidas a terceros de buena fe a la que se refiere el precepto como condición previa a la demolición de un inmueble ordenada por un juez o tribunal, no precisa la tramitación de un procedimiento contradictorio, ni requiere que tales indemnizaciones hayan sido fijadas como debidas en un procedimiento de responsabilidad patrimonial o en un incidente de ejecución de sentencia en el que se declare y reconozca el derecho del tercero y 
determine la cantidad liquida que resulte exigible por el mismo". (FD 80 Sentencia 476/2018, de 21 de marzo).

Se considera el art. 108.3 por estas Sentencias, como un trámite integrado en la ejecución, que comporta la adopción por el órgano judicial de medidas de aseguramiento para responder del pago de las indemnizaciones que puedan reconocerse a terceros de buena fe al margen del proceso. Estas medidas han de ser valoradas atendiendo a los datos y elementos del juicio de que disponga y pueda recabar en el procedimiento, resolviendo las controversias que surjan en el incidente de ejecución. Por ejemplo en el caso de la Administración Publica, que está exenta de prestar garantías, se pueden adoptar medidas consistentes en la fijación de un plazo perentorio para que realice la correspondiente modificación presupuestaria e incluso la imposición de multas coercitivas para que lleve a término estas obligaciones.

Finalmente la STS de 25 de mayo de 2018, Recurso 325/2016, de la que es ponente Cesar Tolosa Triviño, reafirma una delimitación positiva y negativa sobre el tercero de buena fe. En cuanto la delimitación positiva, su ámbito subjetivo "no puede circunscribirse a la de terceros de buena fe protegidos, por la fe pública registral, sino que ha de extenderse a todos aquellos que puedan hacer valer un derecho a ser indemnizados, en su condición de terceros perjudicados". Y por otra parte "la condición de terceros de buena fe no puede predicarse exclusivamente de los titulares de edificaciones que constituyan su vivienda habitual o el lugar donde desarrollar su actividad profesional, dado que tal restricción supondría dejar fuera de la protección del precepto el grueso de los supuestos reales que suelen afectar a residencias vacacionales o segundas residencias".

En cuanto a la delimitación negativa de la condición de terceros de buena fe, se excluye al promotor que obtuvo la licencia declarada nula porque, "como titular de la licencia ha sido parte en el proceso y, en consecuencia, no puede ser considerado tercero". Y en segundo lugar porque el art. 108.3 LJCA "viene a salvaguardar los intereses de terceros que no son titulares de la licencia cuyos derechos pueden verse afectados por la demolición de la obra amparada en la licencia sin haber sido parte en el proceso". Se ratifica, en definitiva, la doctrina del TS, consistente que no siempre los terceros propietarios deben ser considerados tercero de buena fe (STS 3 de noviembre de 2015, RC 1782/2014). 


\section{LA IMPOSIBILIDAD LEGAL Y MATERIAL DE EJEGUGIÓN DE LAS SENTENCIAS}

\section{Ideas Generales}

La imposibilidad de ejecutar las Sentencias podrá ser por imposibilidad legal o material. Se fundamenta en el art. 18.2 de la Ley Orgánica del Poder Judicial y art. 105.2 LJCA. La competencia para declarar que concurren alguna de estas circunstancias le corresponde al Poder Judicial. Como muy acertadamente señala Fernández Valverde ${ }^{55}$, si se examina "la realidad actual, bien pudiéramos distinguir entre imposibilidad por causa legal, imposibilidad por causa reglamentaria o administrativa e imposibilidad por causa material".

En efecto, la obligación de ejecutar la Sentencia en sus propios términos, también puede ser enervada por la aprobación de una nueva Ley. Ante esta nueva Ley no se aplica lo previsto en la LJCA, puesto que el control de legalidad de una ley estatal o autonómica le corresponde al Tribunal Constitucional. Este tema fue abordado por la STC 73/2000, ${ }^{56}$ en relación con la imposibilidad legal de ejecutar el fallo que anulaba la puesta en marcha de la Presa de Itoiz como consecuencia de la aprobación de una nueva norma legal. En esta Sentencia el Tribunal declara que una modificación del marco normativo, efectuada por una norma de rango legal puede determinar la imposibilidad legal de proceder a la ejecución de un fallo judicial.

Ahora bien, en su Fundamento Jurídico $11^{\circ}$ deja claro que: "aun siendo indudable que la Constitución reconoce al legislador un amplio margen de libertad al configurar sus opciones, no es menos cierto que también le somete a determinados límites. Y en lo que aquí interesa, no sólo al genérico límite antes aludido de la interdicción de la arbitrariedad de los poderes públicos (art. 9.3 CE) y al que impone al principio de igualdad (art. $14 \mathrm{CE)} \mathrm{sino} \mathrm{también} \mathrm{al} \mathrm{límite} \mathrm{que} \mathrm{se} \mathrm{deriva} \mathrm{del} \mathrm{art.} \mathrm{24.1} \mathrm{CE.”} \mathrm{Y} \mathrm{por}$ ello cuando "no exista la debida proporción entre el interés encarnado en la Ley y el concreto interés tutelado por el fallo a ejecutar." "cabría estimar que tal Ley sería contraria al art. 24.1 en relación con los arts. 117.3 y $118 \mathrm{CE}$, al faltar la debida proporción «entre la finalidad perseguida y el sacrificio impuesto".

En segundo lugar, se viene incluyendo, como dice Fernandez Valverde, dentro de imposibilidad legal, lo que no es más que una simple imposibilidad de carácter

55 FERNÁNDEZ VALVERDE, R., "La Ejecución de las Sentencias en el ámbito urbanístico", Revista de Urbanismo y Edificación. $2^{\mathrm{a}}$ Parte, $\mathrm{N}^{\mathrm{o}}$ 21, 2010.

56 Véase comentarios de FERNÁNDEZ VALVERDE, R., "La Ejecución de las Sentencias en el ámbito urbanístico." $1^{\text {a }}$ Parte. Revista de Urbanismo y Edificación. No 20, 2009 y (2010). Y SÁNCHEZ GOYANES, E., Problemática en la ejecución de las Sentencias urbanísticas, Fornadas Nacionales sobre interpretación y Aplicación de las Sentencias Urbanísticas, 2014. 
administrativo o reglamentario, lo que se produce frecuentemente en el ámbito del planeamiento urbanístico.

La discrecionalidad de la Administración Pública inherente a la potestad planificadora no puede modular los efectos de las ilegalidades y fundamentar el nuevo planeamiento en función del carácter aprovechable de lo anterior, pues señala la STS de 27 de octubre de 2015, Rec 313/2.014, no es de recibo la "metodología seguida para la normalización urbanística”, llevando a cabo una valoración conjunta de las diversas infracciones a través de los denominados coeficientes de ponderación de la naturaleza de la infracción. Y ello es así porque estamos en una diferente regulación del art. 103.1 de la LJCA, con respecto a la Ley 39/1956, de una manera totalmente contraria, señalando de acuerdo con la $\mathrm{CE}$, que "la potestad de hacer ejecutar las sentencias y demás resoluciones judiciales corresponde exclusivamente a los Juzgados y Tribunales de este orden jurisdiccional." La Administración, como parte está obligada a cumplir la Sentencia y también está obligada a prestar la colaboración requerida por los Jueces y Tribunales (arts. 103.2 y 3) como Administración Pública, una vez que sea firme esta sentencia, pues el órgano que hubiera realizado la actividad del recurso, y reciba la comunicación del Secretario judicial, deberá llevar "a puro y debido efecto" lo que exija el cumplimiento de las declaraciones contenidas en el fallo (art. 104.1 LJCA). Si la Administración incumple la ejecución de la Sentencia en los plazos señalados, se podrá proceder a su ejecución forzosa, a la imposición de multas coercitivas a autoridades, funcionarios, a agentes que incumplan los requerimientos, hasta la completa ejecución del fallo judicial, así como deducir el oportuno testimonio de particulares para exigir la responsabilidad penal que pudiera corresponder, (arts. 112 y 113 LJCA). Por ello, sin alterarse los términos en que la disputa procesal fue planteada y resuelta, no puede pretenderse privar de efectos, posteriormente, al pronunciamiento judicial. Sólo es posible de acuerdo con el principio de congruencia, si concurren elementos que impidan física/jurídicamente la ejecución o la dificulten por circunstancias sobrevenidas impeditivas. En efecto, como hemos dicho anteriormente, si concurren causa de imposibilidad material o legal, el órgano obligado a su cumplimiento lo comunicará al Tribunal para que adopte las medidas para su mayor efectividad ejecutoria o en su caso la indemnización que proceda por la parte que no pueda ser objeto de cumplimiento pleno de acuerdo con el art.105.2 LJCA.

Sánchez Castro ${ }^{57}$ señala que a pesar que el TS, había considerado, en el ámbito civil, el cumplimiento por equivalente como una partida indemnizatoria derivada del art. 1.101 del Cc, existen una serie de sentencias más recientes del TS en la que

57 SÁNCHEZ CASTRO, J. D. "El cumplimiento por equivalente: ¿un modo de evitar los requisitos imprescindibles en toda prestación indemnizatoria?", Anuario de Derecho Civil. Vol. 63, No 4, 2010. Págs. 1725-1787. 
se considera como un medio autónomo y distinto de la indemnización de daños y perjuicios. La STS, Sala $1^{\text {a }}$ de 23 de Marzo de 2007, distingue perfectamente lo anterior, diciendo lo siguiente: "Para la aplicación del cumplimiento por equivalencia basta que no sea posible el cumplimiento "in natura", o no sea ya útil al acreedor; en cambio para la indemnización de daños y perjuicios del art. 1.101 Gc, es preciso que se prueben éstos, o conste su existencia "in re ipsa" (en la cosa misma), y al nexo causal y concurra un criterio de atribución".

La indemnización sustitutiva deriva de la imposibilidad de ejecutar una sentencia en sus propios términos y es inherente al derecho a la tutela judicial efectiva recogido en el art. 24.1 CE, como dice la STC de 15 de Diciembre de 1998, que pone de relieve que "este Tribunal ha venido considerando también como cumplimiento "en sus propios términos", la sustitución del cumplimiento "por razones atendibles". Esto había sido avalado constitucionalmente en las Ss.TC 58/1983, ("tan constitucional es una ejecución en la que se cumple el principio de la identidad total, entre lo ejecutado y lo estatuido en el fallo como una ejecución en la que por razones atendibles la condena es sustituida por su equivalente pecuniario o por otro tipo de prestación."), 87/1984 ("El derecho o la tutela judicial efectiva se ha de ejercer por los cauces y con los requisitos procesales que cada caso requiera. Claro está que estos requisitos han de ser razonables", por ejemplo, es razonable la presencia personal del acusado en el proceso penal que es un deber, 149/1989. (El derecho a la tutela efectiva "no alcanza a cubrir las diferentes modalidades que puede revestir la ejecución de la Sentencia", aunque "debe plantearse como un posible ataque al derecho a la tutela judicial efectiva las dilaciones injustificados que puedan acontecer en cualquier proceso") entre otras, para las que es plenamente constitucional una ejecución de sentencia que por razones atendibles, el fallo condenatorio es sustituido por su equivalente pecuniario u otro tipo de prestación.

Una de las cuestiones más debatidas sobre la imposibilidad legal o material es el plazo para comunicar al Tribunal la existencia de esta imposibilidad. La Sentencia de 29 de diciembre de 2015, RJ 2015/6436, recoge un estudio de esta cuestión.

El plazo, como regla general, es de dos meses a que se hace referencia en el artículo 104.2 de la LJCA, o bien, en algunos casos, el plazo especial fijado en la Sentencia al que el mismo precepto se remite, por la vía del artículo 71.1.c) de la LJCA. No obstante, el Tribunal Supremo ha venido interpretando, de manera tradicional, con flexibilidad el mencionado plazo, determinando la STS de 30 de enero de 1996 que: "este plazo no puede considerarse de caducidad y el artículo 18 de la Ley Orgánica del Poder Judicial no lo contempla". 
Después de un largo proceso evolutivo puede señalarse que la última doctrina del TS, (como señala la Sentencia de 29 de diciembre de 2015, RJ 2015/6436) consiste en "que el plazo de dos meses, establecido por el citado artículo 105.2 de la Ley Jurisdiccional, no es un plazo de caducidad absoluto, de manera que su inobservancia, si está justificada, no impide promover, transcurrido el plazo de dos meses, el incidente de imposibilidad legal o material de ejecutar las sentencias ", pero que «la ejecución de una sentencia firme no puede quedar supeditada indefinidamente a la promoción sucesiva de incidentes de imposibilidad legal o material de ejecución de una sentencia por causas existentes al momento de haberse promovido el primero ", porque esta pretensión es contraria a lo establecido por el artículo 105.2 de la Ley de esta Jurisdicción y a la jurisprudencia, interpretativa del mismo, y, en definitiva, contradice abiertamente lo dispuesto en los artículos 118 de la Constitución y 103.2 y 3 de la Ley de la Jurisdicción Contencioso-Administrativa».

Ahora bien, esas modulaciones interpretativas, acordes con la finalidad de la norma, de ningún modo significan que el plazo legalmente establecido carezca de toda virtualidad o pueda ser enteramente ignorado. Cabe señalar que la inobservancia del mencionado plazo, "dependiendo de que esa inobservancia sea o no justificada, podrá ser un factor relevante o incluso determinante a la hora de valorar la seriedad del alegato de imposibilidad, y, en definitiva, a la hora de decidir la procedencia de la declaración de imposibilidad de ejecución que se solicita de forma tardía".

En cuanto al inicio del cómputo del plazo anterior, de acuerdo con las Sentencias del TS, de 25 de noviembre de 2009, (recurso (6237/2009) y 29 de diciembre de 2010 (recurso 500/2008), conviene señalar que "no es, pues, el momento de la notificación de la sentencia al representante procesal de la Administración el que determina el inicio del cómputo del plazo para la ejecución voluntaria de la sentencia por parte de la Administración demandada, ya que tal momento será el de la comunicación -realizada de oficio- de la misma sentencia al órgano que hubiere realizado la actividad objeto del recurso".

Por otra parte la jurisprudencia del TS ha establecido que los autos que declaran la inejecutabilidad de una sentencia por imposibilidad material o legal conforme al artículo 105 LJCA eran susceptibles de ser impugnados en la vía casacional atípica como ha reiterado en sentencias de 26 de marzo de 2008 (recurso 4014/2006), 28 de mayo de 2008 (recurso 2900/2003 ), 7 de octubre de 2008 (recurso 4066/2006 ) y 25 de noviembre de 2006, puesto que "...no hay resolución que contradiga más lo decidido en sentencia que aquélla que la declara inejecutable..." Igualmente, entendemos que van a seguir siendo recurso de casación estos Autos después de la reforma introducida en la LJCA por la Ley 7/2015, por su interés casacional objetivo. 


\section{La imposibilidad legal}

\section{A. Delimitación y límites}

La STS, Sala 3 ${ }^{\text {a }}$, Sección $5^{\mathrm{a}}$, de fecha 3-7-2000, recurso 2061/1995 nos dice que "la existencia de una modificación en aquel (se refiere al planeamiento) puede determinar la posterior adecuación de lo construido al mismo, y originar un supuesto de imposibilidad legal de ejecutar la sentencia dictada que ha de ser planteado en trámite de ejecución de sentencia y resuelto por el propio tribunal sancionador".

El Tribunal Supremo tiene reiterado que una de las causas de imposibilidad de ejecutar una sentencia es el cambio del planeamiento derivado del "ius variandi" urbanístico de la Administración.” Y no es porque la revisión del PGOU impida la demolición decretada en una Sentencia, sino que, "al haber variado la normativa aplicable, el edificio se ha convertido en legalizable de forma que iría en contra de las más elementales reglas de la lógica y del respeto de la riqueza creada, al llevar a cabo la demolición de un edificio que podría ser reedificado a renglón seguido" (STS de 30 de noviembre de 1996, de 22 de enero de 1997 y 25 de junio de 1998).

Si bien no puede perderse de vista la postura jurisprudencial de que las legalizaciones posteriores por la vía de alteración del planeamiento vigente deben encontrar adecuada justificación en consideraciones y criterios de Ordenación superiores a la simple voluntad de esa legalización, por todas ellas la STS de 6-6-1.995, recoge que "el ius variandi reconocido a la Administración por la legislación urbanística, se justifica en las exigencias del interés público, y que en la potestad modificatoria de los planes, la Administración no queda vinculada por Ordenaciones anteriores, pudiendo establecer nuevas previsiones sobre clasificación y uso de los terrenos. Y efectivamente ello es así, aunque conviene recalcar que tal facultad innovadora de la Administración materializada en la ordenación territorial propia de un Plan de urbanismo, tiene unos límites propios derivados del necesario acatamiento a los estándares urbanísticos previstos en la legislación general sobre el suelo y su ordenación, no menos que a la adecuada satisfacción de las necesidades sociales y del interés público a cuyo servicio ha de estar subordinada la ordenación territorial con ausencia, en todo caso, de cualquier tipo de arbitrariedad en la solución de los problemas urbanísticos dentro de una realidad social determinada".

También el respeto a las características físicas del suelo pone límite a la imposibilidad legal de ejecutar la Sentencia. Así en la STS de 17 de noviembre de 2018, RJ 2008/5964, resolviendo el recurso de casación interpuesto contra el Auto de la Sala de lo Contencioso Administrativo del Tribunal Superior de Justicia de Andalucía, con sede en Málaga, sobre ejecución de sentencia contra el Ayuntamiento de Estepona que adujo la imposibilidad legal de la ejecución porque en el PGOU de Estepona aprobado en 1994, los terrenos figuran clasificados como Suelo no Urbaniza- 
ble no Programado, lo que haría inviable el otorgamiento de licencia de edificación sin el previo planeamiento de desarrollo. Sin embargo el Alto Tribunal, tras señalar que la Sala de Instancia había declarado en la Sentencia el carácter de urbano de los terrenos y que en ella, no solo hizo una valoración sobre las características físicas de la parcela y sobre su condición de suelo urbano, sino que se emite, "un pronunciamiento claro e inequívoco de reconocimiento de una situación jurídica individualizada, declarando expresamente en la parte dispositiva de la Sentencia el derecho de la recurrente a la concesión de la licencia solicitada. Es este un pronunciamiento en el que no existe ninguna nota de provisionalidad o transitoriedad sino definitivo y concluyente, por lo que no puede considerarse supeditado a las ulteriores vicisitudes del planeamiento", puesto que al amparo del planeamiento nuevo, no pueden ignorarse situaciones de hecho y derecho subjetivos ya reconocidos en Sentencia firme. Sin embargo hay que tener en cuenta, tal como señala la STS de 30 de octubre 2008, Rec. 5853/2006, que el carácter reglado del Suelo Urbano "destierra como ejercicio discrecional de la facultad de planeamiento para materializar tal clasificación, por ello ha de atenderse a la realidad fáctica existente en el momento de aprobarse el instrumento de planeamiento". Y en consecuencia, si se establecen los servicios urbanísticos con posterioridad, no por ello se le confiere cobertura jurídica a las obras realizadas. Puede originar todo lo más "una dificultad en la ejecución, que no de una imposibilidad legal en su cumplimiento".

\section{B. Requisitos}

Siguiendo sustancialmente la STS, de 4 de febrero de 2009, Recurso 1745/2007, de la que es ponente Rafael Fernández Valverde, existen algunos criterios materiales en relación con los requisitos precisos para la concurrencia de causa de imposibilidad legal de ejecución, como consecuencia de una modificación del planeamiento urbanístico, entre los que destacan los siguientes:

a) La modificación del planeamiento no produce una legalización automática "ex post facto", de todas las edificaciones que resulten conformes con el nuevo aunque no lo fueran con el anterior. Por ello, cuando medie una Sentencia anulatoria de una disconformidad con la nueva ordenación no deja sin efecto dicha Sentencia, sino que "acaso pudiera constituir un supuesto de imposibilidad legal de su ejecución".

La STS de 28 de septiembre de 2012, RJ 2012/9512, dice que ni siquiera una legalización formal a través de un Plan Especial, sí no solventa la auténtica "ratio decidendi" de la sentencia, es decir, el incumplimiento de la integración en el conjunto y la contemplación del paisaje, puede constituir causa de inejecución de una sentencia por imposibilidad legal.

b) Si la modificación del planeamiento se lleva a cabo con la intención de que la sentencia no se ejecute, dicha innovación no conllevará la inejecución de la reso- 
lución judicial, (Ss.TS de 30 de noviembre de 1996, de 22 de enero de 1997 y de 25 de junio de 1998). En el mismo sentido las SsTS, de 20 de diciembre de 2003 y 4 de mayo de 2004, reiteran que "eran nulos de pleno derecho los actos y disposiciones contrarios a los pronunciamientos de las Sentencias, que se dicten con la finalidad de eludir su cumplimiento".

c) En el caso que la Administración Pública ejercite el ius variandi sobre el planeamiento en actuaciones declaradas ilegales en Sentencia firme, tendrá que demostrar que la ordenación tiene como finalidad "atender racionalmente al interés público urbanístico".

La Administración mantiene sus facultades para la Ordenación Urbanística y por tanto podrá modificar el planeamiento, pero cuando afecte a actuaciones y edificaciones declaradas ilegales por Sentencia judicial firme, tendrá que justificar y demostrar que la finalidad del ejercicio de sus facultades de Ordenación tienen como objeto el interés público y no resolver una situación particular, buscando eludir el cumplimiento de la ejecución de una Sentencia. miento.

d) La imposibilidad legal requiere la aprobación definitiva del nuevo planea-

La STS de 29 de junio de 2002 admitió que se podía dejar sin efecto la demolición acordada, si las obras ejecutadas son habilitadas por las determinaciones de un nuevo planeamiento, habilitando la posibilidad de espera en el cumplimiento de la resolución adoptada en su momento a la aprobación del instrumento de planeamiento, cuando exista posibilidad de su legalización, dado que consideraba que en este caso, el interés público no se ve gravemente afectado por la eventual tardanza en la materialización de la demolición si ello en su día se ratificara como procedente.

Siguiendo esta línea jurisprudencial, el Tribunal Superior de Justicia de Andalucía, Sala de Málaga, había dictado una serie Autos referidos al PGOU de Marbella, como el de 11 de Enero de 2.008, en los que acordaba aplazar la decisión sobre la procedencia de la demolición hasta el momento de la aprobación definitiva del Plan, que se encontraba tan solo aprobado inicialmente.

Sin embargo la Sentencia del Tribunal Constitucional 22/2009, de 26 de Enero de 2009, ha desautorizado esta línea jurisprudencial señalando que "la decisión judicial de suspender la demolición acordada en Sentencia firme, en expectativa de una futura modificación de la normativa urbanística que, eventualmente, la legalizará, supone una vulneración del art. 24.1 CE, en su vertiente de derecho a la ejecución de las resoluciones judiciales firmes en sus propios términos" y por ello "no puede admitirse que suponga un supuesto de imposibilidad legal o material la mera expectativa de un futuro cambio normativo, toda vez que ello no implica alteración 
alguna de los términos en los que la disputa procesal fue planteada y resuelta". La STG 254/2015 reitera la anterior doctrina constitucional señalando que las sentencias firmes de demolición de construcciones ilegales han de ser ejecutadas aun cuando resulten conformes con el planeamiento en tramitación.

Ruíz Bursón ${ }^{58}$ señala que también debe considerarse como exigencia de imposibilidad legal, la legalización mediante licencia u otra autorización administrativa del acto objeto de disputa procesal, citando al respecto las SsTS de 13 de junio, 26 de septiembre y 4 de octubre de 2006, 6 de febrero de 2007 y 4 de febrero y 29 de abril de 2009. Aunque esta exigencia no es admitida por todos. ${ }^{59}$

\section{La imposibilidad material}

En lo referente a la imposibilidad material, el avance actual de la técnica, determina que en puridad nada es imposible de ejecutar materialmente. Habrá de analizarse si esta imposibilidad material, se refiere más bien a actuación desproporcionada, costosa o dificultosa de la "restitutio in natura". En opinión de Gifreu Font ${ }^{60} \mathrm{c}$ ) "En la práctica este supuesto ha sido pretextado como una vía para eludir el derribo de edificaciones ilegales, cuando la ejecución del fallo, aunque físicamente compleja por el concurso de dificultades técnicas o jurídicas, es del todo posible". La STS de 17 de Diciembre de 2010 consideró de imposibilidad material, en el Municipio de Villaviciosa, la ejecución de la sentencia, por encontrarse la finca ya urbanizada, y ejecutadas las obras. En el mismo sentido la STS 25 de Septiembre de 2.015, considera imposibilidad material la reposición a origen de una urbanización, totalmente ejecutada por el Ayuntamiento de Valladolid. Llegándose incluso, en la Sentencia del Tribunal de Justicia de Castilla León, casada por el TS, a considerar, no sólo que era imposible la "restitutio in natura" de las fincas sino que no tendría ventaja para nadie, ni siquiera para quien la solicitaba, y "que bien podría decirse que al efectuar una solicitud de esa índole parte de la irreversibilidad o prácticamente irreversibilidad de unos hechos consumados para hacer un ejercicio abusivo de su derecho". Es indudable que los aspectos técnicos son claves en esta cuestión, cuando ponen de relieve, por ejemplo, que la "única solución técnica viable en este caso sería la demolición total del edificio. Dicha afirmación se apoya en cálculos precisos de estructuras que vienen a demostrar que la demolición del fondo de edificio dejaría al mismo tan profundamente afectado que sería totalmente inviable no solo para garantizar en lo sucesivo la seguridad de las personas residentes en el inmueble, sino

58 RUÍZ BURSÓN, F. J., "Las Innovaciones en el Planeamiento urbanístico como causa de imposibilidad legal para la ejecución de Sentencias", Revista General de Derecho Administrativo. No 33,2013.

${ }_{59}$ Véase GÓMEZ-FERRER RINCÓN, R., La imposibilidad de ejecución de sentencias en el proceso contencioso-administrativo, Editorial Civitas, 2008.

60 GIFREU FONT, J. (2017). 
para permitir la ocupación del mismo". Hay que tener en cuenta que "la sentencia no ordena la demolición total del edificio para reducirlo a solar, sino una demolición parcial del mismo que se ha revelado como técnicamente inviable" (STS de 27 de julio de 2001RJ 2001/8327).

También se considera imposibilidad material cuando afecta a un servicio esencial (Auto TS, de 19 de enero 1994, RJ/1994/50), como es el caso de un acuífero, porque tendría "como resultado práctico la falta de prestación de tan esencial servicio público, de vital trascendencia social y sanitaria" lo que tiene como efecto jurídico la inejecución de la sentencia por "material imposibilidad de su cumplimiento dadas tales trágicas consecuencias".

La Sentencia del TS de 23 de febrero de 2010, acerca de un convenio sobre el nuevo desarrollo de Anoeta (San Sebastián) deja claro, no obstante, el carácter restrictivo del concepto, de imposibilidad material que no puede confundirse con una "mera dificultad técnico jurídica de reponer jurídicamente, la situación surgida como consecuencia de la incorrecta licitación, a la situación debida".

Por tanto, si para ejecutar lo juzgado, el órgano judicial adopta una resolución que ha de ser cumplida por un ente público, éste tiene que llevarla a cabo con la necesaria diligencia, sin obstaculizar el cumplimiento de lo acordado, por imponerlo el art.118 CE, y en otro caso, el juez adoptará las medidas necesarias para su ejecución sin dilaciones indebidas. El art.103.2 de La LJCA centra la obligación del cumplimiento de las Sentencias en las partes procesales. Pero la obligación de colaboración para su ejecución, según el artículo 118 CE y el art.103.3 LRJCA se amplía a todas las personas y entidades públicas y privadas. No obstante, el órgano jurisdiccional valorando las observaciones efectuadas, en relación con la imposibilidad legal o material de ejecución de las Sentencias, decidirá lo procedente en cada caso concreto, por lo que no se puede pretender "aislar o blindar jurídicamente situaciones de infracción judicialmente declaradas al socaire de un nuevo -e incluso integral y completo- planeamiento frente a la potencialidad jurídica de una resolución de un órgano judicial".

A veces confluyen la imposibilidad legal y material. Esto suele ocurrir porque en la realidad la aprobación de un nuevo planeamiento comporta en el ánimo del juzgador, una inclinación de entender legitimado, a través de él, las situaciones deslegitimadas por la anulación de un Plan previo. Así se puede apreciar en la STS de 9 de febrero de 2009, RJ 2009/3217, que señala que la Sala de instancia adoptó la decisión, luego confirmada por el Tribunal Supremo, de anular los acuerdos del Ayuntamiento de Soria por los que se aprobaba definitivamente la delimitación de la unidad de actuación de un polígono industrial y se adoptaba para dicha unidad el sistema de actuación el de expropiación. Posteriormente se suceden una serie incidencias y trámites seguidos en relación con el cumplimiento de la sentencia y como 
consecuencia la Sala de instancia declara la imposibilidad legal y material de su ejecución, ordenando el inicio de los trámites encaminados a fijar de la indemnización compensatoria. Hay que tener en cuenta que la revisión del PGOU de Soria de 1994 supuso la desaparición de las causas que motivaban la nulidad de las actuaciones urbanísticas que se habían practicado con lo que había dado lugar a la consolidación de situaciones legales al amparo del nuevo marco urbanístico que habían de ser respetadas en esta ejecución. De ahí que la única solución para intentar ejecutar la sentencia era la contenida en el auto recurrido que debía ser confirmado, puesto que el Tribunal Supremo entendía que no procedía la "restitutio in natura", al haber sido declarado conforme a derecho el PGOU de Soria, al no haberse admitido el recurso de casación interpuesto contra su aplicación y en consecuencia "todas las licencias y actuaciones urbanísticas, realizadas quedan convalidadas sin que los titulares de dichas licencias y derechos adquiridos con base en las actuaciones urbanísticas que han recibido la oportuna cobertura legal tengan que verse afectados por la satisfacción de los legítimos intereses de los recurrentes ejecutantes." En el mismo sentido que la anterior, la STS de 25 de enero de 2011, RJ 2011/499, sobre la construcción en Boiro de una planta de cogeneración, establece la inejecución por imposibilidad legal, tras el cambio de planeamiento declarado conforme a derecho por Sentencia firme y por imposibilidad material, puesto que como consecuencia de lo anterior se permite la declaración de utilidad pública de determinada construcción y el otorgamiento de licencia de obras que legaliza las realizadas, así como licencia de actividad.

\section{GONGLUSIONES}

\section{Mayor dificultad actual de la ejecución de las sentencias urbanísticas}

La especial dificultad de ejecución de las sentencias contencioso-administrativas originada esencialmente por una falta de colaboración de la Administración, se ha mejorado en los últimos años, como consecuencia principal de la modificación experimentada en el artículo 103.1 de la Ley 29/1998 de 13 de julio reguladora de la Jurisdicción Contencioso-Administrativa, que atribuyó la potestad de ejecución en exclusiva a los juzgados y tribunales en lugar de a la Administración Pública, pero esta mejora no puede predicarse igualmente de la ejecución de las Sentencias en el ámbito urbanístico.

\section{Mejoras de la legislación urbanística y exigencia de voluntad política para remediar las causas que ocasionan la falta o la demora en la ejecución de las sentencias urbanísticas}

Es necesario disponer de mecanismos preventivos y represivos efectivos para evitar el hecho consumado de las viviendas ilegales. Todo pasa por una continua 
mejora de la legislación urbanística autonómica, que entre otras cosas arbitre una regulación mejor de la protección de la legalidad y restauración física de las construcciones ilegales así como de las parcelaciones ilegales. Por otra parte de nada serviría esta mejora legislativa si no va acompañada de una auténtica voluntad política tanto autonómica como municipal, que en caso de no producirse debe ser exigida de manera efectiva por el poder judicial.

\section{Modificación de la regulación de los planes urbanísticos} para atenuar la nulidad radical y limitación de la impugnación indirecta de la acción pública para evitar la indefinida interinidad de los planes

La consideración mayoritaria por la doctrina y la jurisprudencia de los planes urbanísticos como Reglamento ha comportado que cualquier defecto jurídico, formal o sustantivo, provoque la nulidad de pleno derecho. Ello unido al abuso de la acción pública, así como la reiterada utilización de su impugnación indirecta, ha traído consigo una gran interinidad en su vigencia anulándose muchos planes al cabo de largo tiempo de su aprobación, lo que ha provocado un gran trastorno social, económico y jurídico.

Existen algunos pronunciamientos jurisprudenciales, así como una determinada legislación comparada y doctrinal que abren una vía de gran interés para solucionar o atenuar los problemas que afectan a la nulidad de los Planes. Sustancialmente tienen en común, la distinción entre los actos, trámites y el Plan en sí, así como entre los defectos formales y los sustantivos. Existe una relevante doctrina que, compartimos, que propugna su clarificación, mediante la inclusión en una Ley.

\section{El desequilibrio entre la obligación legal y el incumplimiento efectivo del derecho a la vivienda de los ciudadanos como freno a la demolición de viviendas ilegales}

Aunque el derecho a la vivienda viene reconocido constitucionalmente, en los distintos Estatutos de Autonomía y en el derecho comunitario, su efectividad dista bastante en España de ser algo garantizado. Por ello, existe una reiterada doctrina jurisprudencial que procura la salvaguarda del domicilio residencial familiar por razones psicológicas y materiales, frenando o retardando en multitud de casos la ejecución de la demolición de edificaciones ilegales si constituyen el domicilio habitual de una persona.

\section{Luces y sombras de las modificaciones generales} administrativas y jurisdiccionales

Mientras que la reforma de la legislación penal no ha incidido demasiado en la ejecución de sentencias de demolición de construcciones ilegales en los delitos de 
ordenación del territorio y urbanismo, sobre todo, por el carácter potestativo de las medidas a adoptar por el juez penal, no ha ocurrido lo mismo con la reforma del art. 108.3 de la LJCA que ha introducido una serie de incertidumbres en su aplicación, referidas especialmente a la obligación de garantizar de manera efectiva las indemnizaciones de los terceros de buena fe. Recientemente se ha ido produciendo una jurisprudencia que ha arrojado más claridad a la interpretación del art. 108.3, que no está exenta de debate. Entre los pronunciamientos de esta jurisprudencia destacan los siguientes:

- El art. 108.3 se convierte en una fase más de la ejecución pero nunca en un impedimento para la ejecución de la sentencia. No es un obstáculo para la ejecución, añade un deber, el de garantizar el reconomiento de los perjuicios para los terceros de buena fe.

- En ningún caso se condiciona la ejecución de la sentencia a la resolución de expediente de responsabilidad alguno.

- Se delimita positiva y negativamente el tercero de buena fe. No puede circunscribirse a los terceros de buena fe protegidos por la inscripción registral, tampoco se puede reducir a los propietarios ni a los titulares de edificaciones que constituyan la vivienda habitual. Y se excluye al promotor de la vivienda que obtuvo la licencia declarada nula porque ha sido parte en el proceso y no puede considerarse tercero.

\section{La restricción de la imposibilidad legal y material de cumplir las sentencias en sus propios términos}

Las Sentencias deben cumplirse en sus propios términos salvo imposibilidad legal o material. Por ello, la jurisprudencia ha ido interpretando cada vez más restrictivamente esta posibilidad. La imposibilidad legal tiene que ser provocada por un nuevo ordenamiento urbanístico o territorial, pero no se produce automáticamente, y no puede llevarse a cabo esta aprobación con la intención de que la Sentencia no se ejecute, debiendo justificarse el interés general de la Ordenación.

La imposibilidad técnica, en un sentido estricto, no tiene cabida prácticamente ante los avances tecnológicos. Por tanto, deberá ser construida en base a la desproporción que puede provocar la "restitutio in natura", pero no podrá justificarse en una mera dificultad técnica. 


\section{BIBLIOGRAFÍA}

AGOÚES MENDIZÁBAL, C."Reflexiones sobre el alcance del Recurso indirecto contra Reglamento en relación con los planes urbanísticos. RAP. Na 190. Madrid Enero-Abril 2013.

ALONSO MAS, M ${ }^{\mathrm{a}}$ J. y REVUELTA PEREZ, I. Buena fe contra demolición urbanística. Thonson Reuters Aranzadi 2017.

ALONSO IBÁÑEZ, M. R. "La imposibilidad de ejecución de sentencias de demolición de edificaciones. Medidas Legales. Obra colectiva Por el Derecho y la Libertad. Libro Homenaje al Prof. Juan Alfonso Santamaría Pastor.Iustel ,Madrid 2014.

BLANQUER, D. "Espacios de discrecionalidad en las licencias urbanísticas." Del libro El Derecho de la Ciudad y el Territorio. Estudio en Homenaje a Manuel Ballbé Prunés. 2016.

BETANCORT RODRÍGUEZ, A. "La evolución histórica normativa de la ejecución de Sentencias Contencioso Administrativas". DANº 209. Enero-Abril 1987.

CASANOVA GÓMEZ, G. "La restauración del Plan General de Ordenación Urbana de Madrid tras su anulación parcial por resoluciones judiciales o la perpetua interinidad del Planeamiento General en nuestro país." RDU, N 287. Enero-Febrero 2014 .

DÍAZ MURIAS, R. "El recurso de casación y demoliciones urbanísticas. El Consultor de la Ayuntamientos. $\mathrm{N}^{\circ}$ 13, Sección Opinión/Comentarios de Jurisprudencia, Quincena del 15 al 29 de Julio. 2017, Ref.: 1737/2017.

DE COMINGES CÁCERES, F. "Los efectos de la anulación judicial de un Plan General. La necesaria modulación de la equiparación de Planes Urbanísticos y Disposiciones Reglamentarias. Propuestas de Mejora del Sistema”. RDUMA Núm. 314. Madrid, junio 2017.

DOMÍNGUEZ VILA, A. "El Derecho Constitucional a la Vivienda Teoría y Práctica". RvDU No 271 272. 2012.

ESCRIBANO TESTAUT, P. "Las causas y los efectos directos y colaterales de la declaración de nulidad del PGOU de Ourense". Practica Urbanística. No 121 Marzo-Abril 2013. Editorial La Ley.

FERNÁNDEZ APARICIO, J. M. "Regularizaciones administrativas y su incidencia en los delitos urbanísticos. La demolición"RDU n ${ }^{\circ}$ 284. Septiembre - Octubre 2013. 
FERNÁNDEZ RODRÍGUEZ, T. R.

- "Algunas Reflexiones sobre las formas indirectas de incumplimiento por la Administración de las Sentencias de los Tribunales de la Jurisdicción Contencioso-Administrativo". Revista de Administración Pública, no 73. Enero-Abril 1974.

- "Proceso contencioso-administrativo y urbanismo. Semejanzas y diferencias de los casos francés y español”. Revista de Urbanismo y Edificación. N 29, 2013.

FERNÁNDEZ VALVERDE, R. "La Ejecución de las Sentencias en el ámbito urbanístico." $1^{a}$ Parte. Revista de Urbanismo y Edificación. No 20, 2009 y $2^{\text {a }}$ Parte, $\mathrm{N}^{\mathrm{o}} 21,2010$.

GIEURE LE CARESSANT, J. "Comentarios arts.38 y 39 TRLS08". Obra colectiva Estudio del articulado del Texto Refundido de la Ley de Suelo Estatal, dirigida por Gutiérrez Colomina, Venancio, y Cabral González-Sicilia, Ángel. Ed Thomson/Aranzadi 2009.

GIFREU FONT, J. "Reflexiones críticas en torno al control jurisdiccional de la actividad urbanística de los entes locales". RDU, n 310, Madrid, diciembre 2016.

GÓMEZ-FERRER RINCÓN, R. La imposibilidad de ejecución de sentencias en el proceso contencioso-administrativo. Editorial Civitas 2008.

GUTIÉRREZ COLOMINA, V.

- "La reacción ante las urbanizaciones ilegales". Del libro Urbanizaciones de Iniciativa particular. TAL.N ${ }^{\circ}$ 22. CEMCI de Granada. 1988.

-Régimen jurídico urbanístico del espacio rural: la utilización edificatoria del suelo no urbanizable. Editorial Montecorvo, S.A. Madrid 1990.

- "Comentarios al art. 21.4 de la LOUA sobre parcelaciones en terrenos que tengan el régimen del suelo no urbanizable". Del libro Comentarios a la Ley de Ordenación Urbanística de Andalucía, codirigido por Venancio Gutiérrez Colomina y Angel Cabral González-Sicilia. Ed. Thomson. Aranzadi. Pamplona 2007.

- "Comentario a la disposición adicional cuarta. Gestión de suelos del patrimonio del Estado", del libro Estudio del Articulado del Texto Refundido de la Ley de Suelo Estatal (RD Legislativo 2/2008, de 25 de junio). Dirigido por Venancio Gutiérrez Colomina y Ángel Cabral González-Sicilia. Thomson Aranzadi 2009.

- "La protección de la legalidad en el régimen urbanístico de Andalucía". Practica Urbanística. Nº112. El Consultor. Febrero 2012. 
MEDIAVILLA CABO, J. V. "El artículo 108.3 de la ley Reguladora de la Jurisdicción Contencioso-Administrativa a la luz de la reciente jurisprudencia del Tribunal Supremo. Innecesariedad de indemnizar con carácter previo o simultaneo a la demolición”. RDU. No 322. Junio 2018.

PAREJO ALFONSO, L. "El plan urbanístico no es solo norma. En pro de la superación de la doctrina simplificadora de su naturaleza.” Práctica Urbanística. ${ }^{\circ}$ 144, Sección Estudios. Editorial Wolters Kluwer. La Ley 9895/2016.

PECES MORATE, J. E. "La Justicia en el Urbanismo y el Medio Ambiente: ¿Se cumplen las sentencias?", Revista de Derecho Urbanístico y Medio Ambiente. N $^{\circ}$ 311, Madrid, Enero-Febrero 2017.

PÉREZ ALONSO, J. "El nuevo sistema de casación en el orden contencioso administrativo operado por la Ley Orgánica 7/2015, de 21 de julio, con la vista puesta en el certiorari estadounidense". Diario La Ley. Nº 8621, Sección Tribuna, 8 de octubre de 2015. Ref. D-366, Editorial La Ley.

PLAZA GONZÁLEZ, M. "La nulidad de los instrumentos de Planeamiento General y la Preservación de los actos firmes dictados a su amparo.” RDU. No 312. Madrid - Marzo 2017.

PONGE SOLÉ, J. y FERNÁNDEZ EVANGELISTA, G. "Derecho urbanístico, derecho a la vivienda y personas sin hogar. Nuevos desarrollos y perspectivas en España a la vista de las novedades europeas en la materia” RDU. No 256.

RENAU FAUBELL, F. "La nulidad "radiactiva” de los planes urbanísticos por defectos en el procedimiento de aprobación”. Noticias Jurídicas 10-3-2016.

REVUELTA PÉREZ, I. y E. NARBÓN LAÍNEZ. "Ejecución de Sentencias en materia urbanística, demolición y terceros adquirentes de buena fe. El caso de la anulación de licencias. Revista Crítica de Derecho Inmobiliario. Nº 720.

RUÍZ BURSÓN, F. J. "Las Innovaciones en el Planeamiento urbanístico como causa de imposibilidad legal para la ejecución de Sentencias." Revista General de Derecho Administrativo 33 (2013).

SAMANO BUENO, P. "La ejecución de Sentencias en materia de urbanismo, repaso al estado de las cosas y alguna propuesta”. RDU. N No $^{\circ}$. Diciembre 2007.

SÁNCHEZ CASTRO, J. D. "El cumplimiento por equivalente: ¿un modo de evitar los requisitos imprescindibles en toda pactación indemnizatoria?"Anuario de Derecho Civil. Vol. 63, No 4, 2010. 


\section{SÁNCHEZ GOYANES, E.}

"Extinción jurídica de un plan y supervivencia de sus actos derivados: uniformidad en la diversidad jurisprudencial". Práctica Urbanística. Nº 106, Sección Estudios, Julio 2011. Editorial La Ley.

"Problemática en la ejecución de las Sentencias urbanísticas." Jornadas Nacionales sobre Interpretación y Aplicación de las Sentencias Urbanísticas. 2014.

SANTAMARÍA PASTOR, J. A.

-"Muerte y transformación de la desviación de poder: Sobre las sentencias anulatorias de Planes Urbanísticos”. RAP.N¹95. 2.014.

- "Los Proyectos de Ley del Procedimiento Administrativo Común de las Administraciones Públicas de Régimen Jurídico del Sector Público: Una primera Evaluación". D.A. No 2 Enero-Diciembre 2015.

VAQUER CABALLERÍA, M. "Estudio preliminar" del libro Comentarios a la ley de Suelo de Parejo Alfonso y Roger Fernández. IUSTEL 2007.

VILLALIBRE FERNÁNDEZ, V. El derecho a una vivienda adecuada. Un derecho del siglo XXI. Estudios de Progreso. Fundación Alternatives 2011. 